Review / Artículo de revisión / Artigo de revisão - Tipo 3

\title{
Machine Learning Algorithms for Inter-Cell Interference Coordination
}

Omar Albeiro Trejo Narváez / omartn@unicauca.edu.co

Víctor Fabián Miramá Pérez / vmirama@unicauca.edu.co

Universidad del Cauca, Popayán-Colombia

ABSTRACT The current LTE and LTE-A deployments require larger efforts to achieve the radio resource management. This, due to the increase of users and the constantly growing demand of services. For this reason, the automatic optimization is a key point to avoid issues such as the inter-cell interference. This paper presents several proposals of machine-learning algorithms focused on this automatic optimization problem. The research works seek that the cellular systems achieve their self-optimization, a key concept within the self-organized networks, where the main objective is to achieve that the networks to be capable to automatically respond to the particular needs in the dynamic network traffic scenarios.

KEYWORDS Machine learning; self-organization; ICIC; LTE.

\section{Algoritmos de aprendizaje automáti- co para coordinación de interferencia inter-celda}

RESUMEN Los despliegues actuales de LTE y LTE-A requieren mayor esfuerzo para la gestión de recursos radio debido al incremento de usuarios y a la gran demanda de servicios; en ese escenario, la optimización automática es un punto clave para evitar problemas como la interferencia inter-celda. El presente trabajo recopila propuestas de algoritmos de aprendizaje automático [machine learning] enfocados en resolver este problema. Las investigaciones buscan que los sistemas celulares consigan su auto-optimización, un concepto que se enmarca dentro del área de redes auto-organizadas [Self-Organized Networks, SON], cuyo objetivo es lograr que las redes respondan de forma automática a las necesidades de los escenarios dinámicos de tráfico de red.

PALABRAS CLAVE Aprendizaje automático; auto-organización; ICIC; LTE.
Algoritmos de aprendizado de máquina para coordenação de interferência entre células

RESUMO As implantações atuais de LTE e LTE-A exigem maior esforço para o gerenciamento de recursos rádio devido ao aumento de usuários e à alta demanda por serviços, neste cenário a otimização automática é um ponto-chave para evitar problemas como a interferência entre células. $\mathrm{O}$ presente trabalho coleta propostas de algoritmos de aprendizado automáticos focados na resolução deste problema. A pesquisa busca que os sistemas celulares alcancem a sua auto-otimização, um conceito que faz parte das redes auto-organizadas (Self-Organizing Networks, SON), cujo objetivo é garantir que as redes respondam automaticamente às necessidades dos cenários dinâmicos do tráfego de rede.

PALAVRAS-CHAVE Aprendizado de máquina; redes auto-organizadas; ICIC; LTE. 


\section{Introduction}

The amount of User Equipment [UE] within the large and dense mobile networks has suffered a considerable increase in the latest years (Fernández, González, \& Hernández, 2014) due to the considerable data demand caused by the current requirements of the mobile services (Borkar \& Pande, 2016). In order to support these bandwidth demands, standards such as the so-called Long-Term Evolution [LTE] and Long-Term Evolution - Advanced [LTE-A] are required to perform an adequate radio resource management (Kibria, Villardi, \& Nguyen, 2016; Hu \& Pang, 2012) and to improve their optimization functions. This, seeking to provide a suitable response to the needs of the high traffic density scenarios (Guio \& Hernández, 2013).

There are several alternatives to optimize the radio resources allocation, covering from the low-power cells deploy or Heterogeneous Networks [HetNet] (Hu \& Pang, 2012) towards intelligent resource allocation schemes (Glenn, Imran, \& Evans, 2013). Nevertheless, some lacks are present in these proposals since they are not able to adapt themselves dynamically and efficiently to the scenarios with variable network traffic; this entails problems such as the Inter-Cell Interference [ICI] (Fernández et al., 2014).Within the alternatives to achieve dynamic adaptation, the machine learning techniques involving the Self Organization Networks [SON] are present (Van den Berg et al., 2008). These ones include areas such as the self-optimization via decision algorithms, applicable to the frequency reuse to reduce the ICI, making to achieve the automation through the learning over previous actions (5GAmericas, 2013).

In the mobile networks field, the SON concept has been considered by organizations such as the 3rd Generation Partnership Project [3GPP] (Feng, 2008) and the Next Generation Mobile Networks [NGMN] (Behjati, 2014). Within the $3 \mathrm{GPP}$, some SON functionalities are added from the release 8 in environments with several providers (3GPP, 2014), until release $10 \& 11$ where more advanced features such as HetNets, enhanced Inter-cell Interference Coordindation [eICIC], and coordination between SON functions - among others - are supported (5GAmericas, 2013). For the particular case of the NGMN, some use cases for SON are defined (Glenn et al., 2013).

The desired automation to classify a network as self-organized can be achieved through Machine Learning [ML] algorithms (Jiang et al., 2017), which consists of a series of tools widely used nowadays due to their ability to perform predictions from a set of abstract rules. When the ML techniques are combined with the current data analysis capacities and computing power, their predictive capacity is widely enhanced; this entails the achievement of adequate

\section{Introducción}

El número de Equipos de Usuario [Users Equipment, UE] de las redes móviles con gran densidad ha tenido un crecimiento considerable en los últimos años (Fernández, González, \& Hernández, 2014), debido al gran consumo de datos provocado por los requerimientos de los servicios móviles actuales (Borkar \& Pande, 2016). Para soportar estas exigencias de ancho de banda se requiere que estándares como LTE [Long Term Evolution] y LTE-A [Long Term Evolution - Advanced] realicen una buena gestión de los recursos radio (Kibria, Villardi, \& Nguyen, 2016; Hu \& Pang, 2012) y mejoren sus funciones de optimización, para responder con calidad a las necesidades de los escenarios de alta densidad de tráfico (Guio \& Hernández, 2013).

Para optimizar la asignación de recursos existen diversas alternativas que van, desde el despliegue de celdas de menor potencia o Redes Heterogéneas [Heterogeneus Networks, HetNet] (Hu \& Pang, 2012), hasta esquemas inteligentes de asignación de recursos (Glenn, Imran, \& Evans, 2013); sin embargo, se presentan algunos vacíos en estas soluciones, ya que no se adaptan de forma dinámica y eficiente a los escenarios variables del tráfico de red, lo cual produce problemas como la Interferencia Inter-Celda [Inter-Cell Interference, ICI] (Fernández et al., 2014). Dentro de las alternativas para lograr adaptación dinámica se encuentran las técnicas de aprendizaje automático que involucran el concepto de redes auto-organizadas [Self Organization Networks, SON] (Van den Berg et al., 2008), las cuales incluyen áreas como la auto-optimización por medio de algoritmos de decisión, aplicables al reuso de frecuencia para reducir la ICI, que logran automatización a través del aprendizaje sobre acciones previas (5GAmericas, 2013).

En el campo de las redes móviles, el concepto de SON se ha tenido en cuenta en organizaciones como: el Proyecto de Cooperación en Sistemas de Tercera Generación [3GPP, 3rd Generation Partnership Project] (Feng, 2008) y las Redes Móviles de Próxima Generación [Next Generation Mobile Networks, NGMN] (Behjati, 2014). En el 3GPP se incluyen funcionalidades SON a partir de la actualización 8 (release 8) (3GPP, 2014) en entornos de varios proveedores, hasta en las versiones 10 y 11 , donde se soportan funciones más avanzadas que incluyen HetNets, ICIC mejorada [Enhanced Inter-Cell Interference Coordination, eICIC] y coordinación entre funciones SON, entre otras (5GAmericas, 2013). En el caso de NGMN se definen casos de uso para SON (Glenn et al., 2013).

La automatización que se busca para que una red se considere auto-organizada se puede lograr a través de algoritmos de Aprendizaje de Máquina [Machine Learning, ML] Jjiang et al., 2017), que son herramientas muy valoradas actualmente por su capacidad de realizar predicciones a partir de un conjunto de reglas abstractas, y que al combinarse con las capacidades actuales de análisis de datos y procesamiento de cómputo, aumentan su capacidad predictiva, lo que conlleva a conseguir buenos resultados (Rayón, 2017). ML define varios enfoques que se incluyen en el presente trabajo, aplicables al contexto de la auto-optimización, entre ellos: aprendizaje reforzado (Moysen, Giupponi, Carl, \& Gauss, 2014), Q-Learning (Kumar, Ka- 
nagaraj, \& Srilakshmi, 2013; Gadam, Ahmed, \& Kyun, 2016), aprendizaje estadístico (Sierra \& Marca, 2015) y clasificación de patrones (Thilina, Choi, Saquib, \& Hossain, 2013), entre otros.

El presente trabajo recopila los conceptos básicos de algunos de los algoritmos de aprendizaje automático más utilizados en ICIC, tanto para LTE/LTE-A, como para HetNets, trabajos que se enfocan en lograr sistemas auto-organizados. En la sección de metodología se describe la estructura y el orden del documento.

\section{Metodología}

Se realiza una breve revisión inicial del modelo de canal LTE y del proceso general de reuso de frecuencia, así como de la clasificación de las técnicas de reuso de frecuencia, incluyendo técnicas fraccionales, para así comprender el problema de la interferencia en la asignación de recursos. Posteriormente, se incluye una clasificación de las técnicas de aprendizaje automático más utilizadas, no solo en LTE/LTE-A, sino también en redes heterogéneas aplicables a la ICI. La revisión literaria se realiza sobre trabajos de los últimos cuatro años que incluyen propuestas especializadas que buscan auto-organización a través de algoritmos de aprendizaje. Finalmente se presentan algunas conclusiones que sirven de referente para investigación en el área.

\section{Coordinación de interferencia inter-celda en redes LTE}

A. Acceso múltiple por división de frecuencias ortogonales [OFDMA] y reuso de frecuencia

En redes LTE/LTE-A se presentan dos clases principales de interferencias: intra-celda e inter-celda [ICI]. La primera se produce entre canales de frecuencia dentro de la misma celda y gracias a OFDMA y a su serie de subportadoras (FIGURA 1) es muy reducida (Fernández et al., 2014); la ICI se produce entre un canal de frecuencia en una celda y el mismo canal utilizado en otra celda adyacente. LTE/LTE-A tienen aún el reto de resolver este problema, en especial en las regiones de borde de celda (Abusaid \& Salem, 2017), dado que el reuso de frecuencia es de 1.

En la Figura 2 se muestran los escenarios para la ICI entre estaciones base; la Figura 2a muestra el problema de usar la misma banda de frecuencia en una celda adyacente, un tipo de ICI que se puede reducir a través de la asignación de diferentes bandas de frecuencia a las celdas vecinas, tal como se muestra en la Figura 2в (Hamza, Khalifa, \& Hamza, 2013).

Para la asignación de recursos de frecuencia, la ICIC hace uso de la mínima unidad de asignación de recursos, llamada Bloque de Recursos [Resource Block, RB] (Keysight Technologies, 2018). Un RB ocupa $180 \mathrm{KHz}$ de banda, equivalente a 12 subportadoras espaciadas $15 \mathrm{KHz}$ entre ellas, y en él se transmiten 6 o 7 símbolos OFDMA. La duración de un PRB es de 0,5 ms, es decir la duración de una ranura de tiempo. ICIC es una tecnología que busca mejorar el throughput, sobre todo en los bordes de las celdas, intercambiando información entre estaciones base a través de la interfaz X2 (ETSI, 2018); el 3GPP no especifica algoritmos o métodos de control, por lo que deja a los proveedores implementar sus propias soluciones (Dai \& Hiroyuky, 2012). results (Rayón, 2017). ML defines several approaches included in the current paper and applicable to the self-optimization context. The most relevant are: reinforced learning (Moysen, Giupponi, Carl, \& Gauss, 2014), Q-Learning (Kumar, Kanagaraj, \& Srilakshmi, 2013; Gadam, Ahmed, \& Kyun, 2016), statistical learning (Sierra \& Marca, 2015), and pattern classification (Thilina, Choi, Saquib, \& Hossain, 2013), among others.

The present paper gathers the basic concepts of some of the most employed ML algorithms in ICIC, both for LTE/ LTE-A and HetNets. These works are focused on achieving self-organized systems. We describe the structure and order of this document in the following section.

\section{Methodology}

We started by doing a brief revision of the LTE channel model and the general frequency reuse process, such as the classification of the frequency reuse techniques - including fractional techniques - to gather a larger understanding of the interference problem in the resource allocation. After, we include a classification of the most employed machine learning techniques, not only in LTE/LTE-A, but also in heterogeneous networks applicable to the ICI. The literature review was performed in research works of the last four years including specialized proposals seeking for self-organization through ML algorithms. Finally, we present some conclusions that might be useful as a reference in the area.

\section{Inter-Cell Interference Coordina- tion in LTE Networks}

\section{A. Orthogonal Frequency-Division Multiple Access [OFDMA] and} Frequency Reuse

Two main interferences are present in LTE/LTE-A networks: intra-cell and inter-cell. The first one is produced between frequency channels within the same cell and thanks to OFDMA and its series of subcarriers (see FIGURE 1), its impact is low (Fernández et al., 2014). Alternatively, the ICI is produced between a frequency channel in a cell and the same channel used in an adjacent cell. LTE/ LTE-A still have the challenge to solve this issue, particularly in the edges of the cells (Abusaid \& Salem, 2017) because the frequency reuse is 1 .

In Figure 2, we show the scenarios for the ICI between base stations; Figure 2A presents the problem of using the same frequency band in an adjacent cell: an ICI type that can be reduced through the allocation of several frequency bands to the neighbor cells. Figure 2B shows this latter (Hamza, Khalifa, \& Hamza, 2013).

For the frequency resource allocation, the ICIC employs the minimal resource allocation unit called Resource Block 


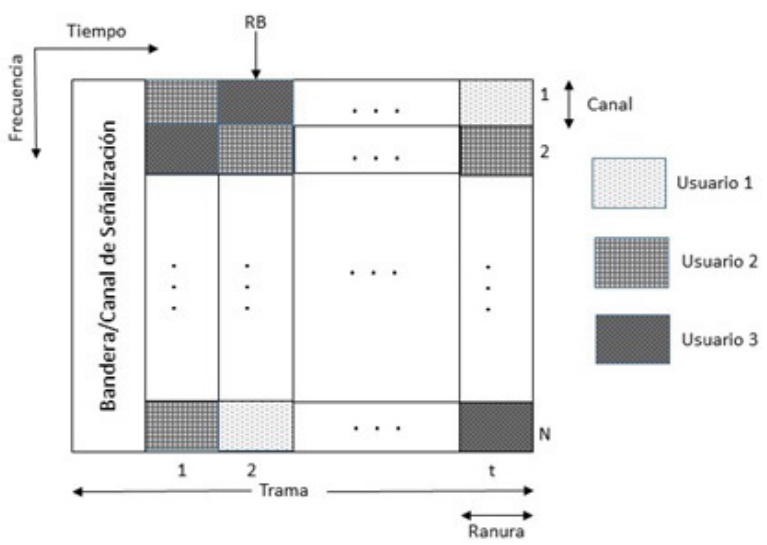

Figure 1. Basic frame structure in OFDMA systems / Estructura básica de tramas en sistemas OFDMA (Hamza et al., 2013)

[RB] (Keysight Technologies, 2018). An RB employs 180 $\mathrm{kHz}$ of band, equivalent to 12 subcarriers spaced $15 \mathrm{kHz}$ among them; in an RB, 6 or 7 OFDMA symbols are transmitted. The duration of an RB is $0.5 \mathrm{~ms}$-i.e., the duration of a time slot-. ICIC is a technology seeking to improve the throughput, especially in the cell edges by exchanging information between base stations through the X2 interface (ETSI, 2018). The 3GPP does not specify algorithms or control methods; hence, the service providers can implement their own solutions (Dai \& Hiroyuky, 2012).

\section{B. Classification of Frequency Reuse Schemes}

\section{Static ICIC Based on the Frequency Reuse}

Within the static models, the optimal values for several parameters such as power, number of sub-bands, and assigned frequencies per cell do not present variations. Hence, these ones are determined in function of environments with

\section{B. Clasificación de esquemas de reuso de frecuencia}

\section{ICIC estática basada en la reutilización de frecuencias}

En los modelos estáticos, los valores óptimos para diferentes parámetros, tales como: potencia, número de sub-bandas y frecuencias asignadas a cada celda, no tienen variaciones, por tanto se determinan en función de escenarios con tráfico fijo. Dentro de estos modelos se incluyen esquemas de planificación de frecuencias convencionales (Reuso-1 y Reuso-3, también llamados Hard Frequency Reuse), y esquemas de Reuso de Frecuencia Fraccional [Fractional Frequency Reuse, FFR] (Budihal, Siddamal, \& Banakar, 2016), los cuales se describen en el siguiente apartado. A pesar de sus diferencias, estos esquemas requieren especificar parámetros comunes como el conjunto de canales (sub-bandas) a utilizarse en cada celda, la potencia y la región de la celda donde se usan las sub-bandas y el centro de celda o borde de celda.

\section{Reuso de frecuencia fraccional}

Este tipo de esquema separa las bandas de frecuencia asignadas a las áreas lejanas de una estación base fijando un reuso de frecuencia de 3 , para las regiones centrales la potencia de transmisión se reduce y se aplica reuso de frecuencia de 1 (FIGURA 2C). Con esto se mejora la Relación Señal a Ruido más Interferencia [Signal Interference Noise Ratio, SINR] y el throughput para UE de los bordes de celda. Algunos esquemas FFR en Hamza et al., (2013) se describen a continuación:

\section{Reuso de Estricto de Frecuencia [StrictFR]}

Este esquema utiliza dos sub-bandas que tendrán una reutilización de frecuencia diferente. Se usa una sub-banda común del ancho de banda del sistema en cada interior de celda (Reuso-1), mientras que la otra parte del ancho de banda se divide entre los eNB vecinos, como en la reutilización de frecuencia dura (reutilización de frecuencia N, N>1), para crear una sub-banda con un bajo nivel de interferencia entre células en cada sector.
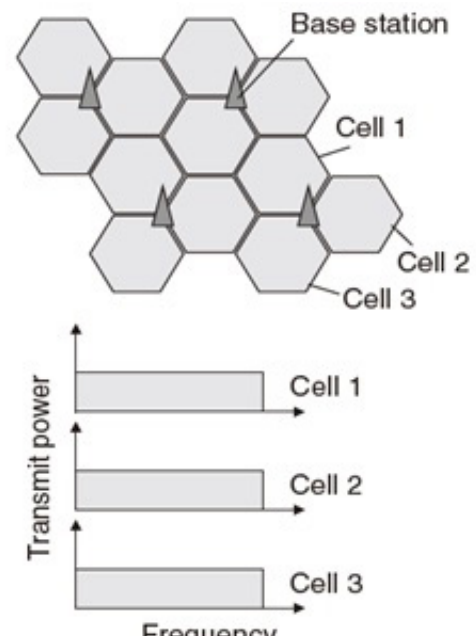

Frequency
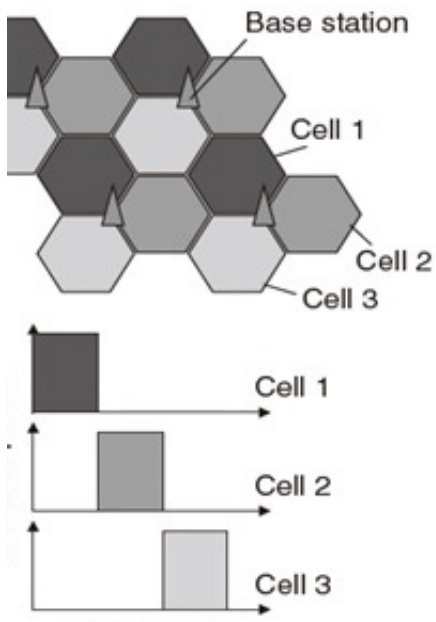

Frequency
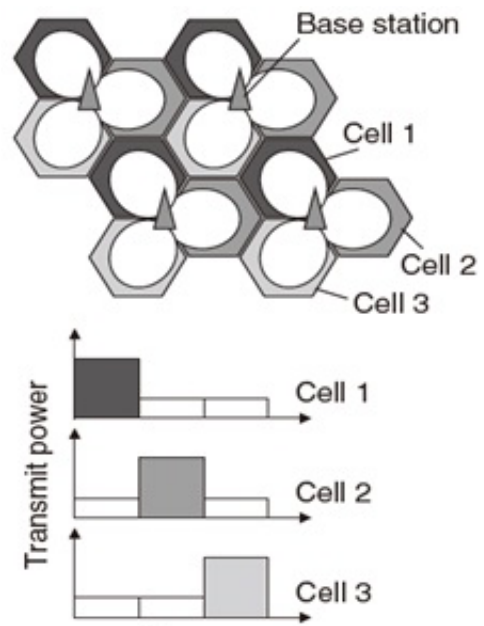

Frequency

Figure 2. Frequency allocation methods in the ICIC technology (Dai \& Hiroyuky, 2012): frequency reuse 1 (a); frequency reuse 3 (b); fractional frequency reuse, frequency reuse 3 for cell edges (c) / Métodos de asignación de frecuencia, tecnología ICIC (Dai \& Hiroyuky, 2012): rehuso de frecuencia 1 (a); reuso de frencuencia 3 (b); reuso de frecuencia fraccional, reuso de frecuencia 3 para bordes de celda (c) 

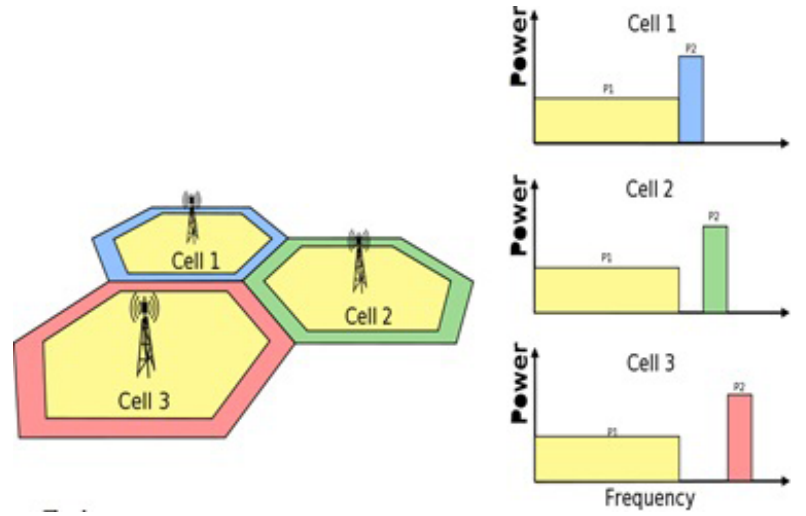

Figure 3. Strict FR scheme with power and frequency plan / Esquema Strict FR con plan de frecuencia y potencia ("ns-3...", 2011)

Los UE de centro recibirán los fragmentos de frecuencia completamente reutilizados, mientras que los UE de borde de célula, los fragmentos ortogonales. Significa que los UE internos de una celda no comparten ningún espectro con los UE de borde de la segunda celda, lo que reduce la ICI (ver Figura 3).

\section{Reuso de Frecuencia Suave [SFR]}

Para este tipo de esquema se tienen dos versiones: en la primera, la sub-banda dedicada para los UE de borde de celda también puede ser utilizada por los UE de centro de la celda, pero con un nivel de potencia reducido y solo si no está ocupada por los UE de borde de célula, la sub-banda del centro celular está disponible solo para los UE centrales (FIGURA 4A); en la segunda, los UE del centro de celda no tienen acceso a la sub-banda de borde de celda, de esta forma, cada celda puede usar todo el ancho de banda del sistema mientras reduce la interferencia a las celdas de los vecinos (Figura 4B).

\section{Reuso de Frecuencia Fraccional Mejorado [EFFR]}

Xie (2009) describe EFFR como un esquema que mejora el rendimiento de los esquemas anteriores, así como la capacidad del sistema en situaciones de sobrecarga. Este esquema define tres tipos de reuso para las células vecinas y reserva para cada tipo de celda una parte de la banda de frecuencia completa, denominada segmento primario, que entre los diferentes tipos debe ser ortogonal. Los subcanales restantes constituyen el segmento secundario. El segmento primario de un tipo de celda es al mismo tiempo parte de los segmentos secundarios que pertenecen a los otros dos tipos de celda. Cada celda puede ocupar todos los subcanales de su segmento primario si lo requiere, mientras que esta celda solo puede utilizar una parte de los subcanales del segmento secundario de forma que tome en cuenta la interferencia (FIgura 5). Dado que cada eNB necesita conocer la ubicación de los segmentos primarios y secundarios de otros tipos de celdas, los calculará suponiendo que la configuración es la misma para cada celda y asumirá solo los desplazamientos de ancho de banda como diferentes (Mohamed \& Abd-Elnaby, 2016).

ICIC dinámica basada en esquemas intra-celda de reuso inteligente

Dentro de esta clasificación se incluyen esquemas dinámicos de nivel bajo, intermedio y alto (Hamza et al., 2013). Dentro del fixed traffic patterns. In these models, some conventional frequency planning schemes are included (e.g., reuse 1 and reuse 3, also called hard frequency reuse). Further, other Fractional Frequency Reuse [FFR] schemes are also included (Budihal, Siddamal, \& Banakar, 2016), which are described in the following section. Regardless of their differences, these schemes require to specify common parameters such as the channels set (sub-bands) to be used in each cell, the power and region of the cell where the sub-bands are used, and the center and edge of the cell.

\section{Fractional Frequency Reuse}

This scheme separates the allocated frequency bands to distant areas of a base station by fixing a frequency reuse of 3 . For the central regions, the transmission power is reduced and a frequency reuse of 1 is applied (see Figure 2c). By doing this, it is possible to improve the Signal to Interference plus Noise Ratio [SINR] and the throughput for the UE in the cell edges. Some FFR schemes presented by Hamza et al., (2013) are described as follow:

\section{Strict Frequency Reuse [StrictFR]}

This reuse technique uses two sub-bands having different frequency reuse. A common sub-band from the system bandwidth is used inside the cell (reuse 1), whilst the other part of the bandwidth is divided between the neighbor eNB - similar to the hard frequency reuse where $\mathrm{N}$ is the frequency reuse and $\mathrm{N}>1-$, to create a sub-band with a low ICI level on each sector.

The UE in the center will receive the frequency fragments completely reused, whilst the UE in the edges will receive the orthogonal fragments. This means that the internal UE in a cell do not share any spectrum with the UE in the edges of the second cell, reducing the ICI (see Figure 3).

\section{Soft Frequency Reuse [SFR]}

For this scheme, two versions are available: in the first one, the dedicated sub-band for the edge UE also can be used for the UE in the center of it, but with a reduced power level and only if it is not busy by the edge UE. The subband for the center is available only for the central UE (see Figure 4A). The second version consists of the UE in the center without access to the edge sub-band; hence, each cell can use all the system bandwidth while the interference to the neighbor cells is reduced (see Figure 4B).

\section{Enhanced FFR [EFFR]}

Xie (2009) describes EFFR as a scheme improving the performance of the previous one, also the system capacity in high-load situations is improved. This scheme defines three reuse types for the neighbor cells and it reserves a part of the complete frequency band (primary segment) for each cell type. Within the different cell types, the band has to 


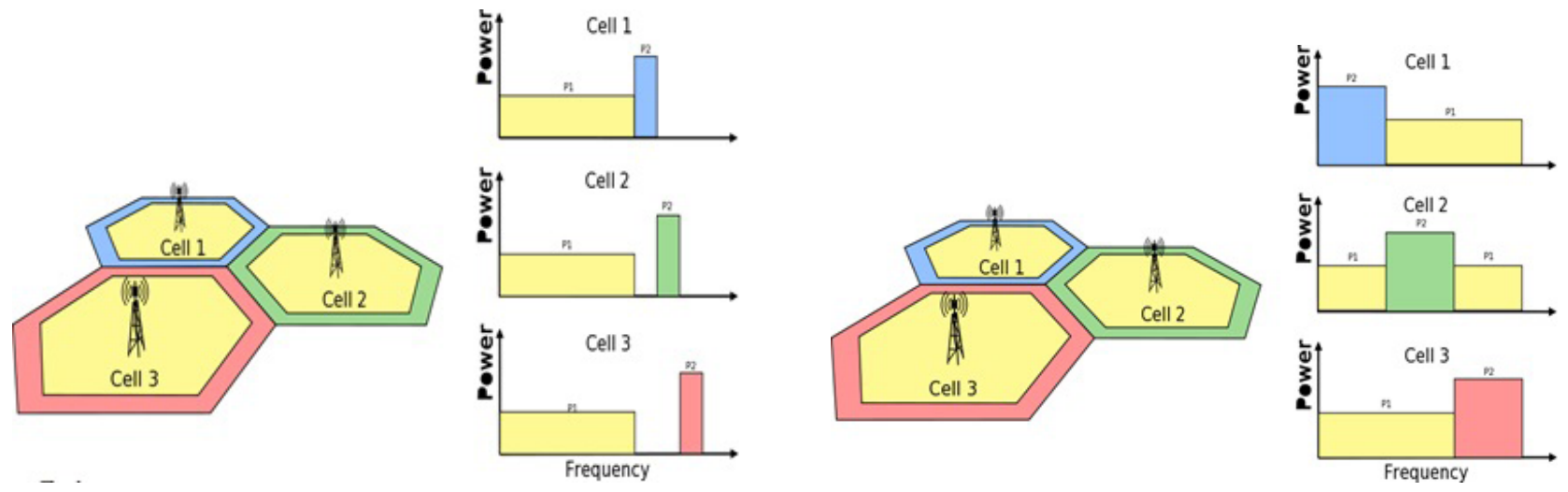

Figure 4. SFR schemes: SFR version 1 (a); SFR version 2 (b) / Esquemas SFR: SFR versión 1 (a); SFR versión 2 (b) (“ns-3...”, 2011)

be orthogonal. The remaining subchannels are the secondary segment. The primary segment of a cell type is, at the same time, part of the secondary segments belonging to the other two cell types. Each cell can use all the subchannels in a primary segment if required, whilst this cell can only use a part of the subchannels of its secondary segment by considering the interference (see Figure 5). Due to the fact that each eNB needs to know the location of the primary and secondary segments of other cell types, the eNB will calculate them assuming that the configuration is the same for each cell and it will also assume only the bandwidth displacements as different (Mohamed \& Abd-Elnaby, 2016).

\section{Dynamic ICIC Based on Intra-Cell Schemes with Inte- lligent Reuse}

Within this classification, it is possible to include dynamic schemes with low, intermediate, and high level (Hamza et al., 2013). In the first group, some configuration parameters previously planned and optimized are present for each case, based on the different traffic loads and UE distributions. Hence, the Base Stations [BS] exchange information. For intermediate level schemes, the calculation of the optimal values is done according to the amount and distribution of UE in each cell. This is done from available data of the cells without limiting to use predetermined configurations. In the high-level schemes, an improvement relative to the intermediate level is present due to the way how the optimal values are calculated. These parameters include the power relation, number of sub-bands, and frequencies allocation. Additionally, the number of sub-bands to be assigned to each UE is calculated in function of the channel condition. Variations of FFR schemes can be used also.

\section{ICIC Dynamic Schemes Based on the Inter-Cell Coordination}

This schemes type seeks to explore the ICIC via management and control models and through the coordinated information exchange among cells by achieving adaptable

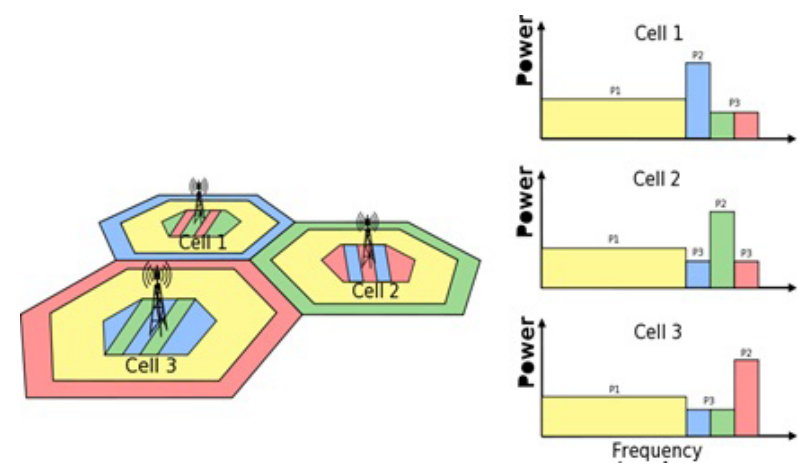

Figure 5. EFFR scheme / Esquema EFFR (“ns-3...", 2011)

primer grupo se tienen algunas configuraciones de parámetros previamente planificados y optimizados para cada caso, basados en las diferentes cargas de tráfico y en las distribuciones de UE, para lo cual las Estaciones Base [Base Station, BS] intercambian información. Para esquemas de nivel intermedio, el cálculo de valores óptimos se hace de acuerdo con la cantidad y la distribución de UE en cada celda, a partir de datos de celdas disponibles, sin limitarse a usar configuraciones preestablecidas. En los esquemas de alto nivel se presenta una mejora en relación con el nivel intermedio dada por la forma cómo se calculan los valores óptimos, donde se incluyen parámetros como: la relación de potencia, el número de sub-bandas y la asignación de frecuencia; adicionalmente, se calcula el número de sub-bandas a ser asignadas a cada UE en función de su condición de canal. En este tipo de esquemas se pueden usar variaciones de esquemas FFR.

Esquemas dinámicos de ICIC basados en la coordinación inter-celda

Este tipo de esquemas busca explorar la ICIC mediante modelos de gestión y control a través del intercambio coordinado de información entre celdas, para lograr ICIC adaptables a diferentes condiciones de tráfico (Hamza et al., 2013). Se pueden clasificar en cuatro categorías: centralizado, semi-distribuido, coordinado-distribuido y distribuido autónomamente. En la primera categoría, una unidad de control central se encarga de recopilar toda la información de estado de canal y de enviar- 
la de forma coordinada entre cada eNodeB para administrar la asignación de recursos; en la segunda, se coordina generalmente en dos niveles, nivel de entidad central y nivel de eNodeB, con lo cual se busca un intercambio de información más eficiente; en esquemas distribuidos autónomos la coordinación se realiza solo al nivel de eNB, sin el uso de una entidad central para la coordinación, a diferencia de los esquemas coordinados distribuidos, los esquemas distribuidos autónomos no requieren coordinación intranodal, ya que cada eNodeB asigna canales a sus UE utilizando información local recopilada, con lo que se tiene la ventaja de eliminar la sobrecarga de señalización por medio de un algoritmo de planificación, lo cual produce que las decisiones pueden adaptarse más rápidamente al canal.

La auto-organización es un concepto de autonomía clave para la evolución futura de las redes, para lograr una ICIC auto-organizada cada eNodeB debe restringir dinámicamente algunos de sus RB a través de técnicas como el control de potencia, para lo cual se involucran parámetros como los niveles de SINR en los RB recibidos, donde un bajo nivel de SINR indica que un RB está siendo usado por un eNodeB vecino.

\section{Trabajos sobre algoritmos FFR Inteligentes}

Deb (2014) presenta un algoritmo para reducir la ICI basado en la asignación de subtramas vacías [Almost Blank Subframes, ABS] y en la Preferencia de Selección de Celdas [Cell Selection Bias, CSB] enmarcado por los estándares LTE. El algoritmo determina las asociaciones óptimas de ABS y UE a través de dos tareas principales: determinar la cantidad de recursos radioeléctricos que las celdas macro deben ofrecer a las celdas pico y determinar las reglas de asociación que deciden qué UE deben asociarse con celdas pico. En este trabajo: se valida la solución teniendo en cuenta la carga de las celdas, los mapas de interferencia macro-pico y la topología de la red; se evalúa la solución en un escenario real en la ciudad de Nueva York, aplicando el marco de SON; y se maneja la eICIC por medio de la asignación de ABS, lo cual es un punto clave en el reuso de la frecuencia.

Con respecto al uso de esquemas EFFR, Mohamed y Abd-Elnaby (2016) presentan un enfoque denominado SODRA-EFFR [Self-Organized Dynamic Resource Allocation scheme using Enhanced Fractional Frequency Reuse], el cual busca mejorar el desempeño y la cobertura en los bordes de las celdas, mediante la asignación dinámica y auto-organizada de recursos (potencia y frecuencia) a las regiones internas y externas de las celdas en redes basadas en relés para retransmisiones LTE-A. En este esquema, tanto la asignación de la potencia y la frecuencia de enlace descendente para las regiones internas y externas de las celdas, como la asignación de frecuencias entre los eNB y de retransmisión en cada celda, se hace a través de la coordinación entre eNBs vecinos y relés, utilizando la interfaz $\mathrm{X} 2$. El rendimiento del enfoque propuesto se evaluó utilizando simulaciones de Matlab con y sin relés; se compara con diferentes combinaciones de asignación de recursos a las regiones internas y externas de la celda, con factores de reuso 1 y 3 , así como con el esquema de SFR.
ICIC values to different traffic conditions (Hamza et al., 2013). The schemes can be classified in four categories: centralized, semi-distributed, coordinated-distributed, and autonomously distributed. In the first one, a central control unit is in charge of gathering all the information relative to the channel state and send it in a coordinate manner to each eNodeB to manage the resource allocation. The second one presents a general coordination in two levels, eNodeB and central entity; this allows a more efficient information exchange. In autonomous distributed schemes, the coordination is performed only at the eNB level without the usage of a central entity for coordination. Contrary to the coordinated-distributed schemes, the autonomous distributed do not require intranodal coordination since each eNodeB assigns channels to their UE by using local information. This entails an advantage of eliminating the signaling overhead via a planning algorithm, producing that the decisions can be adapted quickly to the channel features.

The self-organization is a key concept relative to autonomy for the future evolution of the mobile networks to achieve a self-organized ICIC on each eNB, it dynamically must restrict some of their RB through techniques such as the power control. This involves parameters such as the SINR levels in the received RB, where a low SINR level indicates that an RB is being used by a neighbor eNB.

\section{Research Works Regarding Intelligent FFR Algorithms}

Deb (2014) presents an algorithm to reduce the ICI based on the allocation of Almost Blank Sub-frames [ABS] and in the Cell Selection Bias [CBS] in the LTE standard. The algorithm determines the optimal associations of ABS and UE through two main tasks: determine the amount of radioelectric resources that the macrocells should offer to the picocells and determine the association rules deciding what UE should associate with picocells. In this research work, the author validates its solution by considering the load in the cells, the macro-pico interference maps, and the network topology. Also, the solution is assessed in a real scenario in New York by applying the SON frame. Further, the eICIC is handled through the allocation of ABS, which is a key point in the frequency reuse.

Regarding the use of EFFR schemes, Mohamed and Abd-Elnaby (2016) present an approach called Self-Organized Dynamic Resource Allocation scheme using Enhanced Fractional Frequency Reuse [SODRA-EFFR], which seeks to improve the performance and coverage in the cell edges through the dynamic and self-organized allocation of resources (power and frequency) to the internal and external regions of the cells in networks based on relays for LTE-A retransmissions. In this scheme, both the power and frequency allocation between the eNB and relative to the 
retransmission in each cell is performed via the coordination of neighbor eNB and relays through the $\mathrm{X} 2$ interface. The performance of this approach was assessed via MATLAB simulations with and without relays. Furthermore, the results were compared using different combinations of resources allocation to the internal and external regions of the cells with reuse factors of 1 and 3, such as with their SFR scheme.

\section{Machine Learning Algorithms in Cellular Networks}

Klaine, Imra, Onireti, and Souza (2017) state that - in a general level - the machine learning algorithms are classified in supervised, unsupervised, and Reinforcement Learning [RL] ones (Razavi, Klein, \& Claussen, 2010). Within the supervised learning, a supervisor is involved to train the system and normally a historical of the data is employed by applying tags to specific feature; this allows to predict the results. In the unsupervised learning there is no supervisor nor tags in the data to predict results, since the expected data are unknown and the system needs to learn by itself. The RL algorithms operate like the unsupervised ones, with the addition of a recompense mechanism in charge of rewarding of penalizing the system according to the decision quality (good or bad). This rewarding mechanism allows that the RL system updates itself continuously.

In order to provide machine learning to the LTE/LTE-A networks, several techniques are classified in the scientific literature. Some examples of this are the Markov models (Galindo-Serrano \& Giupponi, 2013), heuristics (Morozs, Clarke, \& Grace, 2015), fuzzy logic (Razavi et al., 2010), and the genetic algorithms (Gao, Chen, \& Li, 2014), among others (see Figure 6). However, the evolution of these techniques implies a larger complexity in the data processing to ensure the algorithms operate correctly, area currently in research as per the Big Data (Barranco, 2012), a field encompassing ML.

\section{A. Supervised Learning}

In this type of learning, the algorithms receive a set of tagged input and output data; from here, a model or function can be generated from the input/output relation. This allows - through a data collection - to feed the model and train the algorithms to improve its predictions. In the LTE context, the supervised learning is a wide domain and it has several algorithms, each one with its proper specifications and applications. Among the application areas, it is possible to outline the load balancing with statistical regression (Sierra \& Marca, 2015), power control (Supratim \& Monogioudis, 2015), and the dynamic frequency allocation $(\mathrm{Li}$, Peng, Yan,

\section{Algoritmos de aprendizaje automático en redes celulares}

Klaine, Imra, Onireti, y Souza (2017) manifiestan que, a nivel general, los algoritmos de machine learning se clasifican en supervisados, no supervisados y de Aprendizaje Reforzado [Reinforcement Learning, RL] (Razavi, Klein, \& Claussen, 2010). En el aprendizaje supervisado se involucra un supervisor para entrenar al sistema, normalmente se utiliza un historial de datos, aplicando etiquetas a características específicas, con lo cual se puede predecir un resultado. En el aprendizaje no supervisado no se cuenta con un supervisor ni con etiquetas en los datos para predecir resultados, ya que dichos resultados esperados no se conocen y el sistema tendrá que aprender por sí mismo. Los algoritmos de RL funcionan de manera similar al tipo no supervisado, con la adición de un mecanismo de recompensa que se encarga de premiar o penalizar al sistema de acuerdo con la calidad de las decisiones (buenas o malas). Este mecanismo de recompensa permite que el sistema RL se actualice a sí mismo, continuamente.

Para proporcionar aprendizaje automático a las redes LTE /LTE-A, en la literatura se clasifican varias técnicas, entre las que se encuentran los modelos de Markov (Galindo-Serrano \& Giupponi, 2013), la heurística (Morozs, Clarke, \& Grace, 2015), la lógica difusa (Razavi et al., 2010) y los algoritmos genéticos (Gao, Chen, \& Li, 2014), entre otras (Figura 6). Sin embargo, la evolución de estas técnicas implica una mayor complejidad del procesamiento de datos para que los algoritmos funcionen de forma óptima, área que es investigada hoy en día por el concepto de Big Data (Barranco, 2012), campo dentro del cual se encuentra ML.

\section{A. Aprendizaje supervisado}

En este tipo de aprendizaje, los algoritmos reciben un conjunto de datos de entrada y de salida etiquetados, con lo cual se puede generar un modelo o una función a partir de la relación entrada salida, lo que permite, a través de un histórico de datos, alimentar al modelo y entrenar al algoritmo para que pueda mejorar sus predicciones. En el contexto de LTE el aprendizaje supervisado es un dominio muy amplio y tiene varios algoritmos, cada uno con sus propias especificaciones y aplicaciones; entre las áreas de aplicación se encuentran: el balanceo de car-

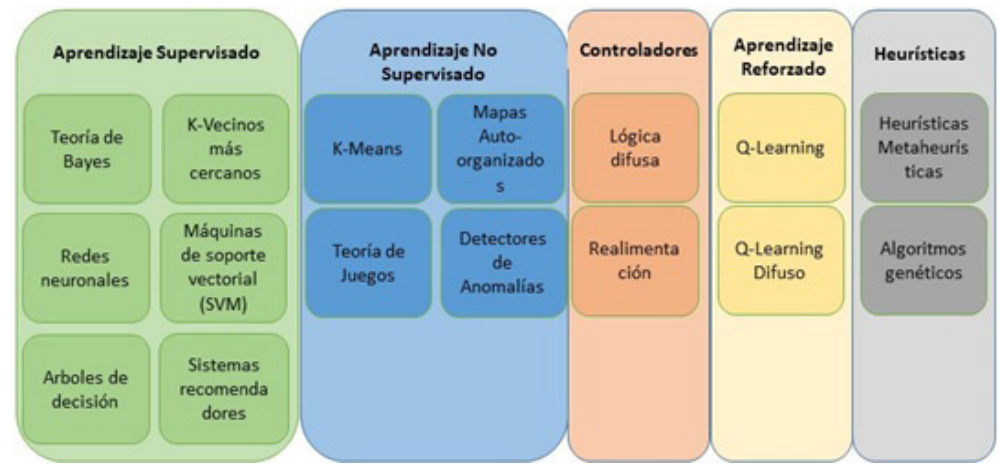

Figure 6. Classification of some machine learning algorithms for ICIC / Clasificación de algunos algoritmos de aprendizaje automático para ICIC (Klaine et al., 2017) 
ga con regresión estadística (Sierra \& Marca, 2015), el control de potencial (Supratim \& Monogioudis, 2015) y la asignación dinámica de frecuencia (Li, Peng, Yan, Zhao, \& Li, 2016). Entre los algoritmos más comunes se encuentran el teorema de Bayes y la regresión lineal, los cuales se describen a continuación.

\section{Teorema de Bayes}

El teorema de Bayes sugerido en Klaine et al., (2017) es una regla importante en el área de la probabilidad y la estadística para el análisis de probabilidades condicionales, es decir, para entender cómo la probabilidad de una hipótesis $(h)$ se modifica por una nueva evidencia (e). El teorema de Bayes está dado por la Ecuación (1).

$$
P(h / e)=\frac{P(e / h) P(h)}{p(e)}
$$

donde:

$P(h / e)$ es la probabilidad de la hipótesis dada la evidencia (a posteriori);

$P(e / h)$ es la probabilidad de la evidencia dada la hipótesis (probabilidad condicional);

$P(h)$ es la probabilidad de la hipótesis (a priori); y

$P(e)$ es la probabilidad de la evidencia (probabilidad total).

El teorema de Bayes es muy utilizado en el área de telecomunicaciones dentro del problema de la ICI. Li, Peng, Yan, Zhao, y Li (2016) estudian la Asignación Dinámica de Recursos de Frecuencia [Dynamic Frequency Resource Allocation, DFRA] a través del despliegue de micro-celdas [Small Cell Base Station, SCBS] siguiendo un modelo de Poisson y logran un esquema adaptativo a través de la aplicación de la teoría bayesiana en el uso espectral correlacionado de las SCBS adyacentes. Para ello, modelan las SCBSs y los UE como un proceso de poisson homogéneo, con intensidades $\lambda_{\mathrm{BS}} \mathrm{y} \lambda_{\mathrm{UE}}$ respectivamente, donde cada UE se asocia con la SCBS más cercana, en espera de que se le asigne una cantidad $\mathcal{N}_{0}$ de sub-portadoras, donde $\mathcal{N}_{0}$ es un valor es preestablecido.

\section{Regresión lineal}

En términos simples, Madariaga, Rodríguez, Lozano, y Vallejo (2013) definen la regresión lineal como un modelo matemático que expresa las relaciones entre una variable dependiente y una o muchas variables independientes, usando una línea recta (línea de regresión), la Ecuación (2) presenta su forma general.

$$
y=a x+b,
$$

donde:

$a$ representa la ordenada, porque su valor es el punto en el cual la línea de regresión cruza el eje vertical; y

$b$ representa la pendiente de la recta.

En el campo de la ICI, a través de esta técnica es posible elaborar un modelo o función (normalmente una recta), a partir de un conjunto: $\mathrm{A}(\mathrm{x}, \mathrm{y}) \in \mathrm{R}^{(\mathrm{n}+1)}$, cuyos elementos serían los parámetros a utilizar. El modelo asume una relación lineal entre
Zhao, \& Li, 2016). Within the most common algorithms, we outline the Bayer theorem and the linear regression, which are described in the following sections.

\section{Bayes Theorem}

The Bayes theorem suggested in Klaine et al., (2017) is an important rule in the probability and statistics areas for the analysis of conditional probabilities, i.e., to understand how the probability of a hypothesis $(h)$ is modified by a new evidence (e). The Bayes theorem is presented in Equation (1).

$$
P(h / e)=\frac{P(e / h) P(h)}{p(e)}
$$

where:

$P(h / e)$ is the probability of the hypothesis given the evidence (aposteriori);

$P(e / h)$ is the probability of the evidence given the hypothesis (conditional probability);

$P(h)$ is the probability of the hypothesis (apriori); and

$P(e)$ is the probability of the evidence (total probability).

The Bayes theorem is widely used in the telecommunications area, punctually in the ICI problem.

Li, Peng, Yan, Zhao, and Li (2016) study the Dynamic Frequency Resource Allocation [DFRA] through the deploy of microcells called Small Cell Base Station [SCBS] and following a Poisson model. They achieve an adaptive scheme through the application of the Bayesian theory in the correlated spectral use of the adjacent SCBS. For this, they model the SCBS and the UE as a homogeneous Poisson process, with intensities $\lambda_{\mathrm{BS}}$ and $\lambda_{\mathrm{UE}}$ respectively. Here, each UE is associated with the closest SCBS waiting an amount $\mathcal{N}_{0}$ of subcarriers, where this $\mathcal{N}_{0}$ is a preestablished value.

\section{Linear Regression}

In simple terms, Madariaga, Rodríguez, Lozano, and Vallejo (2013) define the linear regression as a mathematical model expressing the relations between a dependant variable and one or many independent variables by using a straight line (regression line). Equation (2) presents its general form.

$$
y=a x+b,
$$

where:

$a$ represents the ordinate because its value is the point where the regression line crosses the vertical axis; and

$b$ represents the slope of the line.

In the ICI field, it is possible to elaborate a model or function (generally a straight line) through this technique from a set $\mathrm{A}(\mathrm{x}, \mathrm{y}) \in \mathrm{R}^{(\mathrm{n}+1)}$, where its elements would be the 
parameters to use. The model assumes a linear relation between the $\mathrm{x}, \mathrm{y}$ variablesand it fits in a straight line to the data points (see Figure 7). This relation is expressed through a hypothesis function (Equation 3) to predict a set of outputs (Shanthamallu, Spanias, Tepedelenlioglu, \& Stanley, 2017).

$$
\mathrm{h}(\mathrm{x})=\mathrm{w}_{0}+\mathrm{w}_{1} \mathrm{x}_{1}+\mathrm{w}_{2} \mathrm{x}_{2}+\ldots \mathrm{w}_{\mathrm{n}} \mathrm{x}_{\mathrm{n}}
$$

where:

$$
\begin{aligned}
& \mathrm{x}_{1}, \mathrm{x}_{2}, \ldots \mathrm{x}_{\mathrm{n}} \text { are the parameters; and } \\
& \mathrm{w}_{1}, \mathrm{w}_{2}, \ldots \mathrm{w}_{\mathrm{n}} \text { are the model values. }
\end{aligned}
$$

Sierra and Marca (2015) present a statistical approach based on multivariable polynomial regression consisting of two phases. The first one seeks to find the relation between the explanatory variables: cell traffic state and Cell Range Expansion [CRE] with the dependent variables: Packet Loss Ratio [PLR] and Packet Data Convergence Protocol [PDCP] through a model ruled by the function (4):

$$
z=\beta_{0}+f(x, y),
$$

where:

\section{$x$ is the number of active $\mathrm{UE}$; and}

$y$ the compensation femtocells.

The second phase consists of the CRE displacement selection; the femtocell displacement is dynamically determined by following the model extracted in the previous phase. Hence, the packet loss in the PDPC layer is minimized according to the condition of the traffic in the sector. Finally, a simulation at the system level is performed, where the efficiency of the dynamic CRE is presented.

Bojović, Meshkova, Baldo, Riihijärvi, and Petrova (2016) research the use of several ML techinques combined with statistical regression and they present an approach based on learning to achieve self-optimization in a SON deployment. In their proposal, the learning capabilities are focused on the estimation of KPI within the user and network levels to select the optimal configuration affecting the whole LTE stack. This is done via the Dynamic Frequency and Bandwidth Allocation [DFBA] technique in LTE microcells. They compare their results with other ML approaches, concluding that theirs is a centralized frequency allocation approach for microcells.

Likewise, the authors take as input data the performance measurements in the frequencies configurations, which allows to estimate the impact in the configuration and predict the performance. The results show that the DFBA based on the learning achieves - on average - an improvement in the performance of $33 \%$ relative to the approa- las variables $\mathrm{x}, \mathrm{y}$, y se ajusta en línea recta a los puntos de datos (Figura 7). Esta relación se expresa mediante una función de hipótesis (Ecuación 3) para predecir un conjunto de salidas (Shanthamallu, Spanias, Tepedelenlioglu, \& Stanley, 2017).

$$
\mathrm{h}(\mathrm{x})=\mathrm{w}_{0}+\mathrm{w}_{1} \mathrm{x}_{1}+\mathrm{w}_{2} \mathrm{x}_{2}+\ldots \mathrm{w}_{\mathrm{n}} \mathrm{x}_{\mathrm{n}}
$$

donde:

$$
\begin{aligned}
& \mathrm{x}_{1}, \mathrm{x}_{2}, \ldots \mathrm{x}_{\mathrm{n}} \text { son los parámetros; } \mathrm{y} \\
& \mathrm{w}_{1}, \mathrm{w}_{2}, \ldots \mathrm{w}_{\mathrm{n}} \text { son los valores del modelo. }
\end{aligned}
$$

Sierra y Marca (2015) presentan un enfoque estadístico basado en regresión polinomial multivariable que consta de dos fases. La primera busca encontrar la relación entre las variables explicativas: estado del tráfico de celda y Expansión de Rango Celular [Cell Range Expansión, CRE], con las variables dependientes: Tasa de Pérdida de Paquetes [Packet Loss Ratio, PLR] y Protocolo de Convergencia de Paquetes de Datos [Packet Data Convergence Protocol, PDCP], a través de un modelo denotado por la función (4):

$$
z=\beta_{0}+f(x, y)
$$

donde:

$$
\begin{aligned}
& x \text { es el número de UE activos; y } \\
& y \text { las femto-celdas de compensación. }
\end{aligned}
$$

La segunda fase consiste en la selección de desplazamiento CRE, el desplazamiento de femtoceldas se determina dinámicamente siguiendo el modelo extraído en la anterior fase, de tal forma que se minimice la pérdida de paquetes en la capa PDPC, de acuerdo con la condición de tráfico sectorial. Finalmente, se realiza una simulación a nivel de sistema, donde se muestra la eficacia en la CRE dinámica.

Bojović, Meshkova, Baldo, Riihijärvi, y Petrova (2016) investigan el uso de varias técnicas de ML combinadas con regresión estadística, y presentan una aproximación basada en aprendizaje para lograr auto-optimización en un despliegue tipo SON. En su propuesta, las capacidades de aprendizaje se centran en la estimación de KPI de nivel de usuario y de red,

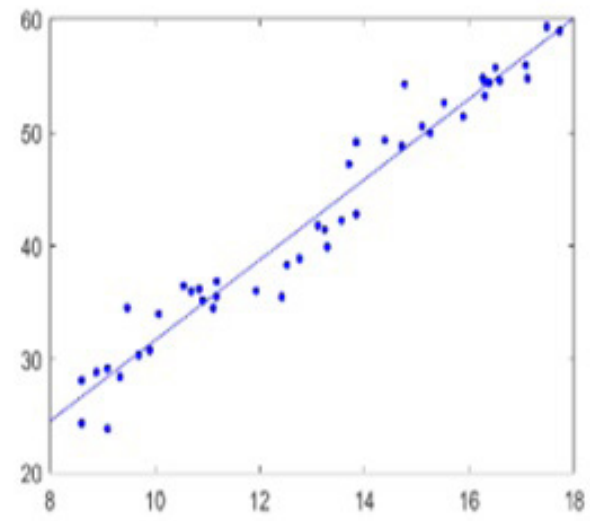

Figure 7. Simple regression with one variable or parameter (Shanthamallu et al., 2017/Regresión simple con una variable o parámetro 
para la selección de la óptima configuración que afectaría toda la pila LTE, lo que se hace explotando el caso de uso para Frecuencia Dinámica y Asignación de Ancho de Banda [Dynamic Frequency and Bandwidth Allocation, DFBA] en micro-celdas LTE, se comparan con otras aproximaciones ML, resaltando que es un enfoque centralizado de asignación de frecuencia para micro-celdas.

De igual forma, se toman como datos de entrada las mediciones de rendimiento en las configuraciones de frecuencias, lo cual permite estimar el impacto de la configuración y predecir el rendimiento. Los resultados muestran que la DFBA basada en el aprendizaje logra en promedio una mejora del rendimiento del 33\% sobre los enfoques que se basan en modelos analíticos, alcanzando el 95\% del rendimiento.

\section{Redes Neuronales [NN]}

Este concepto surgió como un intento de simular en las computadoras el comportamiento del cerebro humano (Hinton, Srivastava, \& Swersky, 2014), que es capaz de realizar cálculos altamente complejos, no lineales y paralelos todo el tiempo. Dividiendo estas funciones en componentes muy básicos, conocidos como neuronas, y dándoles a estas neuronas la misma función de cálculo, un algoritmo simple puede convertirse en una herramienta de cómputo robusta.

Li, Liang, y Ascheid (2016) hacen una propuesta para ICIC mejorada [eICIC] en redes heterogéneas [HetNets], involucrando la relación entre la CRE y las ABS para la asignación dinámica de RB. Se considera un escenario HetNet con multiusuarios, compuesto por un conjunto de macro-celdas $\mathbf{M}=\{1,2,3 \ldots . \mathrm{M}\}$ y un conjunto de pico-celdas $\mathrm{P}=\{1,2,3 \ldots \mathrm{P}\}$, junto con un vector de usuarios en movimiento $\mathrm{U}=\{1,2,3 \ldots . \mathrm{U}\}$. Para mejorar las capacidades de descarga de celdas pequeñas, se usa la estrategia CRE, en la cual se agrega una compensación positiva a la potencia recibida de señal de referencia [Reference Signal Received Power, RSRP] en enlace descendente [DL], de acuerdo con el peso prioritario de cada elemento del vector de usuarios. Esta información, junto con los datos históricos de los usuarios, la información del canal, los patrones óptimos de CRE y ABS, y los vectores de SINR, son los suministros requeridos para entrenar el algoritmo de aprendizaje de red neuronal artificial [Artificial Neural Network, ANN], y lograr, como salida, un patrón de asignación de recursos para usuarios macro y pico.

\section{Máquinas de soporte vectorial [SVM]}

La técnica SVM usa un subconjunto de datos de entrenamiento llamado vectores de soporte, para lo que se aplica un mapeo -lineal o no, tipo polinomial o Gaussiano-, cuyo objetivo es maximizar la distancia entre diferentes clases, es decir, se comporta como un clasificador. Los vectores de soporte son las muestras más cercanas a la zona de decisión, en el caso de la Figura 8 son los círculos verdes que son los puntos más difíciles de clasificar, mientras que la región sombreada denota el límite de decisión óptimo obtenido (Klaine et al., 2017).

Cordina y Debono (2017) estudian técnicas combinadas con SVM, a través de la adaptación de enlaces y de la Programación Selectiva de Frecuencias [Frequency Selective Scheduling, FSS] ches based on analytical models, reaching up to 95\% of the performance.

\section{Neural Networks [NN]}

This concept arose as an attempt to simulate the behavior of the human brain in computers (Hinton, Srivastava, \& Swersky, 2014). The brain is capable of performing highly complex, non-linear calculations in parallel continuously. By dividing these functions in very basic components, known as neurons, and giving them the same calculation function, a simple algorithm can become a robust computing tool.

Li, Liang, and Ascheid (2016) present a proposal for eICIC in HetNets by involving the relation between the CRE and ABS for the dynamic allocation of RB. They consider a HetNet scenario with several users, composed by macrocells $\mathbf{M}=\{1,2,3 \ldots . \mathrm{M}\}$ and a set of picocells $P=\{1,2,3 \ldots \mathrm{P}\}$, together with a vector of moving users $U=\{1,2,3 \ldots . \mathrm{U}\}$.In order to improve the download capabilities of a small cell, the CRE strategy is employed by adding a positive compensation to the Reference Signal Received Power [RSRP] in the downlink [DL] according to the imperative weight of each element of the users' vector. This information together with the historic data of the users-, the channel information, the optimal CRE and ABS patterns, and the SINR vectors are the required supplies to train the machine learning Artificial Neural Network [ANN] algorithm and achieve as output a resource allocation pattern for macro and pico users.

\section{Support Vector Machine [SVM]}

The SVM technique uses a subset of training data called support vectors, where a mapping - linear or non-linear, polynomial or Gaussian - is applied and where the objective is to maximize the distance between several classes; that is, act as a classifier. The support vectors are the closest samples to the decision zone, in the case showed in FiguRE 8 they are the green circles, the most difficult points to classify; whilst that the shaded region indicates the optimal gathered decision limit (Klaine et al., 2017).

Cordina and Debono (2017) study techniques combined with SVM through the adaptation of links and the so-called Frequency Selective Scheduling [FSS] to increase the throughput in mobile services. Through a signaling process, the information delivered by the eNodeB regarding the Channel Quality Indicator [CQI] is used. These data are feedback by the UE data and given that the signaling load increases due to this feedback, a machine learning technique is exploited to address this issue. The authors also propose a new CQI feedback compressing scheme in the sub-bands to predict the channel state through the use of the SVM vector. This information is transmitted to the eNB 


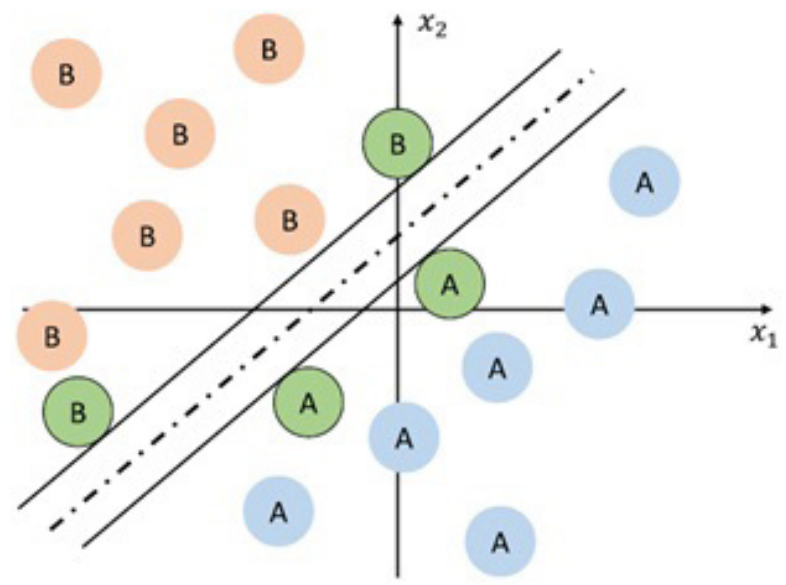

Figure 8. Example of a SVN linear optimal hyperplane / Ejemplo de hiperplano lineal óptimo de SVM (Klaine et al., 2017)

to recover all the channel sub-band response within a configurable error margin.

\section{B. Unsupervised Learning}

In the unsupervised learning, there are no tagged data for the training and the algorithm receives a set of untagged inputs, i.e., the outputs are unknown. Its objective is to search groupings based on similar features to find some structure or way to organize the data (Klaine et al., 2017). Some examples of unsupervised algorithms applicable to ICIC are the game theory (Miramá \& Quintero, 2016), load balancing (Gao et al., 2014), cell interruption management (Moysen et al., 2014), and the genetic algorithms (Trabelsi, Chen, Azouzi, Roullet, \& Altman, 2017). In the following sections, we describe some of the most employed algorithms used for ICIC.

\section{K-Means Algorithms}

This unsupervised learning algorithm is one of the most used in cellular systems (Klaine et al., 2017).Its function is to group data without tags and find their centers from two parameters: the initial dataset and the desired number of clusters (see Figure 9).

Some of its applications can be found in the work of Hajjar, Aldabbagh, and Dimitriou (2015) where, through the grouping and classification of low-power nodes, a Cluster Head $[\mathrm{CH}]$ or main group is selected. This $\mathrm{CH}$ oversees the direct communication with the eNBs; on the other hand, a secondary - or slave - group is also selected to oversee the retransmissions. For the classification, the SINR parameter is employed depending of the service type and the number of associated slaves. Furthermore, a total of 100 RBs are assigned for all the cell, which are distributed one to one in the UE. For the blocked UE, an appropriate $\mathrm{CH}$ from the connected ones is assigned to retransmit their information to the eNB. In this proposal, the $\mathrm{K}$-means algorithm is mixed with the Hierarchical Agglomerative Clustering [HAC] one. para aumentar el throughput en servicios móviles. A través de un proceso de señalización, se usa la información que entrega el eNodeB sobre el Indicador de Calidad de Canal [Channel Quality Indicator, CQD, el cual es retroalimentado a su vez por los UE. Dado que la carga de señalización crece por la retroalimentación, se explota una técnica de aprendizaje automático para abordar este problema y se propone un nuevo esquema de compresión de retroalimentación CQI de subbanda para predecir el estado del canal, a través del uso de los pesos del vector de SVM, información que se transmite luego al eNodeB para recuperar toda la respuesta del canal de subbanda dentro de un margen de error configurable.

\section{B. Aprendizaje no supervisado}

En el aprendizaje no supervisado no se dispone de datos etiquetados para el entrenamiento y un algoritmo recibe un conjunto de entradas no etiquetadas, es decir, se desconocen las salidas. Su fin es buscar agrupamientos basados en características similares para encontrar alguna estructura o forma de organizarlos (Klaine et al., 2017). Ejemplos de algoritmos de aprendizaje no supervisado, aplicables a ICIC, son; la teoría de juegos (Miramá \& Quintero, 2016), el balanceo de carga (Gao et al., 2014), la gestión de interrupción de celda (Moysen et al., 2014) y los algoritmos genéticos (Trabelsi, Chen, Azouzi, Roullet, \& Altman, 2017). A continuación, se describen algunos de los algoritmos más utilizados para ICIC de tipo no supervisado:

\section{Algoritmos K-Means}

Este tipo de algoritmo de aprendizaje no supervisado es uno de los más aplicados en sistemas celulares (Klaine et al., 2017). Su función es agrupar datos sin etiqueta y encontrar sus centros a partir de dos parámetros: el conjunto de datos inicial y el número deseado de clústeres o agrupaciones (FIGURA 9).

Entre las aplicaciones se encuentran el trabajo de Hajjar, Aldabbagh, y Dimitriou (2015), quienes, a través del agrupamiento y la clasificación de nodos de baja potencia, seleccionan un grupo principal o de cabecera [Cluster Head, $\mathrm{CH}$ ], que se encarga de la comunicación directa con los eNBs, y un grupo secundario o esclavo, encargado de las retransmisiones; para la clasificación se usa el parámetro SINR, dependiendo del tipo de servicio y de la cantidad de esclavos asociados. Además, se

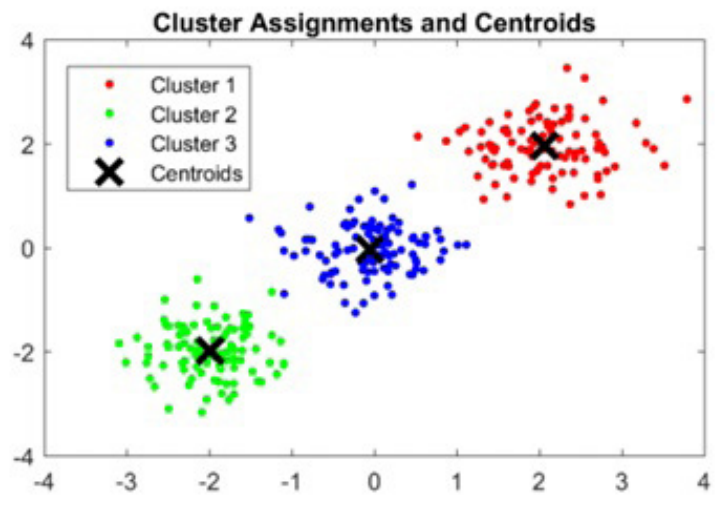

Figure 9. K-Means and the cluster centers / K-Means y los centros de cluster (Shanthamallu et al., 2017) 
asigna un total de 100 RBs para toda la celda, los cuales se distribuyen uno por UE; a los UE bloqueados se les asigna un $\mathrm{CH}$ apropiado de los ya conectados, para retransmitir su información al eNodeB. En esta propuesta se combina el algoritmo K-means con el Agrupamiento Aglomerativo Jerárquico [Hierarchical Agglomerative Clustering, HAC].

En el ámbito de las HetNet, Qi, Zhang, Chen y Zhang (2018) buscan auto-organización para la gran escala de micro-celdas y equilibrio de carga para las distintas potencias de transmisión, a través de un Algoritmo K-Means Basado en el Usuario [User-Based K-means Algorithm, UBKCA], el cual clasifica, en primera instancia, a los grupos de UE del centro para reducir la complejidad computacional, y luego utiliza la GRE y el factor de usuario de borde de celda para mejorar el equilibrio de carga; la óptima combinación de estos dos elementos producen eI CIC, tanto en la precisión, como en el factor de descarga de UE; por medio de los límites de decisión calculados con el algoritmo, se implementa un sistema SON de lazo cerrado. El modelo utilizado define un conjunto de datos $R=\left\{R 1, R 2, R 3 \ldots R_{n}\right\}$, el cual, mediante análisis se divide en k grupos; luego, aleatoriamente se elijen los centros de cada grupo, que se incluyen en un conjunto $O=\left\{01, O 2 \ldots . O_{k}\right\}$, y finalmente se asignan los elementos n-k restantes a su centro más cercano para formar clusters y luego calcular el nuevo centro para cada grupo, repitiendo esta tarea hasta que el sistema converja.

\section{Teoría de juegos}

Esta es una herramienta matemática basada en los postulados establecidos por Neumann, Morgenstern y Nash, este último propuso el concepto del Equilibrio de Nash [Nash Equilibrium, $\mathrm{NE}$ ], el modelado es similar a los algoritmos de RL descritos en el siguiente apartado, donde múltiples agentes toman acciones en un entorno competitivo y al final del juego, dependiendo del resultado de cada agente, se otorga una recompensa o una penalización (Miramá \& Quintero, 2016).

Este tipo de algoritmos puede aplicarse en ICIC, tal como describen Morel y Randriamasy (2017), cuyo trabajo se centra en mejorar la Calidad de Experiencia [Quality of Experience, QoE], métrica distinta a la tradicional Calidad de Servicio [Quality of Service, QoS], la cual evalúa, subjetivamente, cómo un usuario percibe el grado de satisfacción del servicio, dentro de un escenario HetNet con gran demanda de servicio de video HD, es decir, se enfoca sobre una utilidad específica y no sobre el rendimiento general de la red. Este enfoque busca optimizar el período de silenciamiento de macro-celdas y micro-celdas entre eNodeBs y usuarios conectados, a través de un optimizador y un coordinador centralizado, y lograr un impacto directo en la distribución espacial y en la relación SINR, para lo que utiliza los parámetros pares ABS y CIO [Cell Individual Offset] para la selección de los pares óptimos y limitar la interferencia experimentada por los UE de borde de celda, mientras mejora la QoE en la red.

C. Aprendizaje reforzado [RL]

Este método de aprendizaje se asemeja al algoritmo anterior, sin embargo, se centra en los agentes de un sistema, quienes
Within the HetNet topic, Qi, Zhang, Chen and Zhang (2018) seek self-organization for macrocells and load equilibrium for different transmission powers. This is done via a User-Based K-means Algorithm [UBKCA], where it firstly classifies the UE groups in the center to reduce the computing complexity. After, it uses the CRE and the edge user factor to improve the load equilibrium. The optimal combination of these two elements produce CIC, both in accuracy and in the UE download factor. Using the decision limits calculated with the algorithm, a closed-loop SON system is implemented. The used model defines a dataset $R=\left\{R 1, R 2, R 3 \ldots . R_{n}\right\}$ divided in k groupsthrough an analysis. After, there are chosen randomly the centers of each group included in a set $O=\left\{01, O 2 \ldots O_{k}\right\}$, to finally assign the n-kremaining elements to its closest center to form clusters and then calculate the new center for each group. This task is repeated until the system obtains convergence.

\section{Game Theory}

This is a mathematical tool based on the hypothesis established by Neumann, Morgenstern, and Nash. This last proposed the Nash Equilibrium [NE] concept and the modelling is like the RL algorithms described in the following section, where multiple agents take actions in a competitive environment and, at the end of the game and depending of the result of each agent, an award or a penalization are granted (Miramá \& Quintero, 2016).

These algorithms can be applied in ICIC, as Morel and Randriamasy (2017) describe. Their work is focused on improving the Quality of Experience [QoE], a different metric than the usual Quality of Service [QoS]. The QoE subjectively assesses how a user perceives the service satisfaction degree within a HetNet scenario with larger HD video demands. That is, it is focused on a specific utility and not in the general network performance. This approach seeks to optimize the silence period of macro and microcells between eNBs and connected users through a centralized optimizer and coordinator. Besides, it seeks to achieve a direct impact in the spatial distribution and in the SINR by using the ABS and Cell Individual Offset [CIO] parameters to select the optimal pairs and limit the interference caused by the edge UE while the QoE is improved.

\section{Reinforced Learning [RL]}

This learning method is similar to the previous one, with the main difference in being focused on the system agents; they analyze their current status and their environment. According to this analysis, they choose the most adequate action (Miramá \& Quintero, 2016). RL differs from other algorithms in the process performed after the action is chosen (see FIgure 10), which is divided in four steps (Klaine et al., 2017): 
- Policies, which associate statuses with the actions to be taken by the agent;

- Reward function, assessing the current state and gathering a reward or penalization as per the results of the previous performed action;

- Value function, estimating the future reward when the agent applies an action in the current state; and

- Environment model, determining the status and possible actions the agent can take.

The proposal by Moysen et al., (2014) applies an RL approach, where Cell Outage Compensation [COC] is achieved in a self-organized way. This is done by using a learning scheme capable to make online decisions in each eNB. To implement this approach, some concepts such as Temporal Difference [TD] and Actor Critic [AC] are merged, plus a modified FFR scheme.

These tools provide the continuous interaction with the cellular scenario and they allow to learn from experience. Consequently, adaptation for changes in terms of user mobility, coverage and interferences - among others - are achieved. The authors assume the hypothesis that the network has been able to detect the service degradation and identify the interruption to improve the time response using an applied RL to the automatic repairing. This type of approach requires low complexity and it achieves self-organization in an efficient and fast way.

Razavi et al., (2010) combine the fuzzy logic with the reinforced learning through the definition of an efficient learning process via the appropriate reinforcement signal distribution (selection of multiple simultaneous states combined with fuzzy logic). This entails an automatic optimization of the coverage through the adjustment of the downtilt angle and achieving self-optimization. This work highlights among others due to the fact that the reinforced learning states are fed by real input parameters; other similar solutions present the scenario as a finite state Markov decision process (Eberle, 2015). This causes the system to be static and do not consider the environment changes. Although this is an effective solution, it is totally distributed between LTE base stations; the current proposals are centralized such as Bojović et al., (2016) and Supratim and Monogioudis (2015) show. Nevertheless, the scheme presents better performance relative to a similar proposal with learning fuzzy logic rules and optimal parameters are gathered in a global scale for the given scenario. analizan su estado actual y el entorno y, de acuerdo con eso, eligen la acción más adecuada (Miramá \& Quintero, 2016). Se diferencia de otros algoritmos por el proceso que realiza luego de elegir la acción (FIGURA 10), el cual se divide en cuatro pasos (Klaine et al., 2017):

- políticas, que asocian estados con las acciones a tomar por el agente;

- función de recompensa, que evalúa el estado actual y otorga una recompensa o penalización según los resultados de la acción previa realizada;

- función de valor, que estima la recompensa futura cuando el agente aplica una acción en el estado actual; y

- modelo de entorno, que determina los estados y las posibles acciones que puede tomar el agente.

La propuesta de Moysen et al., (2014) aplica un enfoque RL, donde se consigue Compensación de Interrupciones de Celda [Cell Outage Compensation, COC] de forma auto-organizada; utilizando un esquema de aprendizaje capaz de tomar decisiones en línea en cada estación base de nodo mejorado [eNB, evolved Node B]. Para implementar este enfoque, se combinan conceptos tales como: aprendizaje de Diferencia Temporal [Temporal Difference, TD] y Actor Crítico [Actor Critic, AC], además de un esquema modificado de FFR.

Estas herramientas proporcionan la interacción continua con el escenario celular y permiten aprender de la experiencia, con lo cual se logra la adaptación a los cambios en términos de movilidad de usuarios, cobertura e interferencias, entre otros. Los autores asumen la hipótesis de que la red ya ha sido capaz de detectar la degradación del servicio e identificar la interrupción, para así poder mejorar la respuesta en tiempo, mediante el uso de RL aplicado a la reparación automática, ya que este tipo de enfoque requiere baja complejidad computacional y logra auto-organización de forma eficiente y rápida.

Razavi et al., (2010) combinan la lógica difusa y el aprendizaje por refuerzo mediante la definición de un proceso de aprendizaje eficaz, a través de la distribución apropiada de la señal de refuerzo (selección de múltiples estados simultáneos combinada con lógica difusa), logrando optimizar, de forma automática, la cobertura a través del ajuste del ángulo downtilt -ángulo de inclinación de una antena-, es decir, consiguiendo auto-optimización. Este trabajo se destaca debido a que los estados de aprendizaje por refuerzo son alimentados por parámetros de entrada reales, a diferencia de otras soluciones similares, donde el escenario es formulado como un proceso de decisión de Markov de estado finito (Eberle, 2015), lo que hace que sean sistemas estáticos que no tienen en cuenta los cambios del entorno. Aunque es una solución efectiva, está totalmente distribuida entre estaciones base LTE, a diferencia de las propuestas más actuales que son centralizadas,
Figure 10. Block diagram of an RL system / Diagrama de bloques de un sistema RL (Klaine et al., 2017) 
como las de Bojović et al., (2016) y Supratim y Monogioudis (2015). Sin embargo, el esquema presenta mejor rendimiento en comparación con una propuesta similar de reglas de lógica difusa para aprendizaje, y se consiguen parámetros óptimos de configuración a nivel global para el escenario dado.

\section{Q-Learning}

El enfoque Q-learning [QL] es un tipo de algoritmo RL donde un agente crea una tabla de q valores. Al explorar el entorno, la función q actúa como función de valor, estimando recompensas futuras ante acciones actuales. Los q valores se almacenan en una tabla para cada estado y cada acción posible. Sin embargo, la tabla puede ser bastante compleja e inaplicable para grandes espacios de acción de estado (Daeinabi \& Sandrasegaran, 2014).

QL es un algoritmo muy popular dentro de las aplicaciones para ICIC. Al respecto, Ming, Ye, y Xinyu (2017) proponen un modelo multi-agente QL basado en la asignación de recursos, en el cual se introducen dos paradigmas dentro de un entorno de HetNet: un algoritmo QL distribuido aplicable a las pico-celdas, las cuales aprenden del entorno si deben compartir información; y un algoritmo QL centralizado, donde los diferentes agentes interactúan entre sí compartiendo información de recursos y agendamiento. A diferencia de las aproximaciones RL tradicionales, los algoritmos QL no requieren de un modelo preciso, por tanto, se escoge para aplicarse en la asignación de recursos. El modelo propuesto consta de $M$ macro-celdas; las cuales conforman una capa de $\mathcal{N}$ clusters, junto con $K$ pico-celdas distribuidas aleatoriamente dentro de cada cluster. Asimismo, se definen $U_{m}$ y $U_{p}$ usuarios para las celdas macro y pico respectivamente; cada usuario selecciona la celda a utilizar de acuerdo con el parámetro RSRP y son bloqueados aleatoriamente dentro de las áreas de cobertura, para esto las pequeñas celdas dentro del mismo cluster deben compartir información parcial que lleve a obtener el mejor desempeño.

Por otro lado, QL se puede combinar con otras técnicas, tales como la lógica difusa, como plantean Daeinabi y Sandrasegaran (2014), quienes analizan la CRE que produce ICI en enlace descendente dentro de una HetNet. Como solución se propone un esquema de asignación de ABS dinámico, utilizando un enfoque QL combinado con lógica difusa, lo que permite abordar el problema de una tabla compleja de $q$ valores continuos, convirtiéndola en una tabla con valores discretos que combina datos numéricos y lingüísticos, estos últimos obtenidos a partir de la experiencia del operador. Se incluye un controlador difuso QL que procesa las variables difusas de estado, como son: el número de UE macro y pico, el número de tramas ABS, el throughput de macro UE y SINR. El objetivo del controlador es encontrar el valor $\Delta_{\mathrm{ABS}}$ que se suma al valor de ABS actual para cada macrocelda. Cada eNodeB realiza tareas locales para encontrar este valor y luego usa el valor ABS óptimo para sí mismo y para sus propias pico-celdas.

Morozs et al., (2015) parten del concepto de acceso de espectro dinámico [Dynamic Spectrum Access, DSA en sistemas LTE, para proponer una alternativa mejorada de ICIC, me-

\section{Q-Learning}

The Q-Learning [QL] approach is a type of RL algorithm where an agent creates a table of qvalues. By exploring the environment, the $q$ function acts as a value function by estimating future awards in current actions. The q values are stored in a table for each possible action and state. Nevertheless, the table can be highly complex and non-applicable for large state action spaces (Daeinabi\& Sandrasegaran, 2014).

$\mathrm{QL}$ is a very popular algorithm within the ICIC applications. Ming, Ye, and Xinyu (2017) propose a QL multi-agent model based on the resource allocation, where two paradigms are introduced inside a HetNet environment: a QL distributed algorithm applicable to picocells, which learn from the environment if they should share information; and a centralized QL algorithm, where different agents interact amongst them by sharing resources and scheduling information. Unlike the traditional RL approaches, the QL algorithms do not require a precise model; hence, these latter are chosen to be applied in the resources allocation. The proposed model has $M$ macrocells, which conform a layer of $\mathcal{N}$ clusters together with $K$ picocells randomly distributed inside each cluster. Likewise, $U_{m}$ and $U_{p}$ are defined as users for the macro and picocells, respectively. Each user selects the cell to use according to the RSRP parameter and they are randomly blocked inside the coverage areas. For this, the small cells inside the same cluster must share partial information entailing to gather better performance results.

On the other hand, QL can be combined with other techniques such as fuzzy logic, as Daeinabi and Sandrasegaran (2014) propose. They analyze the CRE producing ICI in the downlink inside a HetNet and as a solution, they propose a dynamic ABS allocation system by using a QL approach combined with fuzzy logic. This allows to tackle the issue of a complex table with $q$ continuous values by transforming it into a table with discrete values combining numerical and linguistic data; these latter are obtained through the operator experience. A QL fuzzy controller is included to process the fuzzy state variables such as the number of macro/micro UE, number of ABS frames, throughput of macro UE, and SINR. The objective of the controller is to find the $\Delta_{\mathrm{ABS}}$ value that is added to the current ABS value for each macrocell. Each eNB performs local tasks to find this value and then uses the optimal ABS value for itself and for its own picocells.

Morozs et al., (2015) start from the Dynamic Spectrum Access [DSA] concept in LTE networks to propose an improved ICIC alternative through a distributed RL algorithm called Distributed ICIC Accelerated Q-learning [DIAQ]. This proposal is also Heuristically Accelerated [HARL] to mitigate the disadvantage that the Q-learning algorithms have relative to require many learning interac- 
tions. Such acceleration is particularly provided in the multi-agent domain, leading the exploration process by using additional heuristic information. The scheme is assessed in a stadium-like simulated scenario. The work also describes a generic hexagonal architecture and the usage of the X2 interface for the exchange of ICIC signals. Here, a central eNB sends ICIC signals to the neighbor eNBs. Additionally, a theoretical analysis of a Bayesian network was performed pursuing a new DSA approach using RL. Consequently, this work presents an interesting combination of learning and heuristic techniques, achieving a significative performance through accelerating the algorithm. This produces important results for the reduced time response, which is similar to the pursued objective: reduce the computing complexity.

\section{Heuristics}

This type of algorithms corresponds to simple schemes governed by a set of rules seeking to take the best decision for the system in a given moment. Because they fit as unsupervised algorithms, they are applied when there is no known solution of a particular problem; however, due to their simplicity, the solutions tend to be approximated and suboptimal. Likewise, the meta-heuristics have a similar approach defined by a set of rules, but they are more complex and higher level, producing more optimal solutions (Klaine et al., 2017).

In the ICIC context, it is possible to combine heuristic techniques with other models such as Supratim and Monogioudis (2015) present.Their proposal called Learning-based Adaptive Power control [LeAP] is a machine learning approach based on data measurements (power control parameters) to manage the interference in the uplink. Their proposal is composed of two key elements: the design of measurements statistics for the UE, basic but concise data, enough to determine interference patterns in the network environment; and the design of two algorithms based on learning, one of them seeking the optimal power control parameters, the other is a fast heuristic capable to be implemented using solvers commercially available. The benefit evaluation of this approach is performed using a complex urban scenario in a train station in the United States, where it is demonstrated that there is an improvement in the data rate in the cell edges. Compared with similar approaches, this solution can be implemented by using a SON server centralized architecture.

\section{Genetic Algorithms [GA]}

These are heuristic algorithms inspired in nature concepts, since they evolve from the development of a solutions family where the most optimal solution is identified after a certain number of generations. Even though they are simple schemes, they are applied in complex problems (Jain, 2017). diante un algoritmo RL distribuido denominado [Distributed ICIC Accelerated Q-learning, DIAQ], el cual además es acelerado heurísticamente [Heuristically Accelerated RL, HARL] para mitigar la desventaja que tienen los algoritmos Q-Learning de requerir muchas iteraciones de aprendizaje, dicha aceleración se da en particular en el dominio multi-agente, guiando el proceso de exploración utilizando información heurística adicional. El esquema se evalúa en el escenario simulado de un estadio. El trabajo además describe una arquitectura hexagonal genérica y el uso de la interfaz X2 para intercambio de señales ICIC, donde un eNB central envía señales ICIC a los eNBs vecinos. Adicionalmente, se realiza un análisis teórico de una red bayesiana para un nuevo enfoque de DSA de tipo RL. Por tanto, este trabajo presenta una combinación interesante de aprendizaje con técnicas heurísticas, con lo cual se logra un rendimiento significativo a través de la aceleración del algoritmo, lo que produce resultados importantes por la respuesta reducida en tiempo, que es similar a lo que se busca: disminuir la complejidad computacional.

\section{Heurísticas}

Este tipo de algoritmos corresponde a esquemas simples que se rigen por un conjunto de reglas buscando tomar la mejor decisión posible para el sistema en un momento dado. Dado que son de tipo no supervisado, estos algoritmos se aplican cuando no se dispone de de una solución conocida a un problema particular, sin embargo, debido a su sencillez, las soluciones suelen ser aproximadas y subóptimas. Asimismo, las metaheurísticas tienen un enfoque similar, definido por un conjunto de reglas, no obstante, son más complejas y de más alto nivel, lo que produce soluciones más optimas (Klaine et al., 2017).

En el contexto de la ICIC se puede combinar técnicas heurísticas con otros modelos, tal como lo presentan Supratim y Monogioudis (2015). Su propuesta, denominada Learning-based Adaptive Power control [LeAP], es un enfoque de aprendizaje de máquina basado en mediciones de datos (parámetros de control de potencia), para la gestión de interferencia en enlace ascendente. La aproximación está compuesta de dos elementos clave: el diseño de estadísticas de medición del UE, datos básicos y concisos, pero suficientes para determinar patrones de interferencia en la dinámica de la red; y el diseño de dos algoritmos basados en aprendizaje, uno de ellos busca los parámetros óptimos de control de potencia, el otro es una heurística rápida que puede implementarse utilizando solucionadores disponibles en el mercado. La evaluación de los beneficios de esta aproximación se realiza mediante un escenario urbano complejo en un metro de Estados Unidos, donde se demuestra que se mejora la tasa de datos en el borde de las celdas. Comparada con enfoques similares, esta solución se puede implementar utilizando una arquitectura centralizada de servidor de SON.

\section{Algoritmos genéticos}

Son algoritmos de tipo heurístico inspirados en conceptos de la naturaleza, dado que evolucionan a partir del desarrollo de una familia de soluciones, donde identifican la solución más óptima, después de un cierto número de generaciones. Aunque son esquemas simples, se aplican en problemas complejos (Jain, 2017). 
Kashaf et al., (2017) proponen un enfoque basado en Algoritmos Genéticos [Genetic Algorithms, GA], para reducir la interferencia en redes LTE y al mismo tiempo mejorar el rendimiento de la red. La solución propuesta opera en un escenario con variaciones en el tráfico, las posiciones de los usuarios y las condiciones de propagación. Estas variaciones son modeladas con funciones no lineales y con funciones de probabilidad. GA es una técnica de aprendizaje automático que modela los procesos biológicos de la evolución, involucrando el concepto de generaciones, que en este caso se representa en un escenario para mejorar los KPI de la red, se simulan varias generaciones y logra así la auto-optimización con los mejores resultados. Los KPI optimizados se denominan tasa de aceptación, tiempo de transferencia de archivos y velocidad de bits promedio. Para el modelado del sistema se tiene en cuenta la frecuencia del sistema dividida en tres sub-bandas - una de borde, dos de región central-. Los usuarios con la peor calidad de canal se asignan en la banda de borde/banda protegida; aunque se encuentran principalmente en los bordes de la celda, también podrían estar en la región central de ella y experimentar condiciones de desvanecimiento. Si la banda de borde de una celda está completamente ocupada, a los usuarios restantes se les asignan PRB en las bandas centrales. Los resultados de las simulaciones muestran mejora en la tasa de aceptación de llamadas y en el throghput.

Gao et al., (2014) proponen la Reutilización de la Frecuencia Fraccional Inteligente [Intelligent Fractional Frequency Reuse, I-FFR] para una red LTE con femtoceldas, teniendo en cuentas dos regiones: la región central [Cell Center Region, CGR] y la región de borde [Cell Edge Region, CER], la que a su vez se divide en sectores y se aplica una combinación de algoritmos genéticos con algoritmos de reconocimiento de grafos, ya que en los esquemas FFR convencionales, la proporción de CGR y el factor de reutilización de frecuencia en CER son fijos; además, los RB se distribuyen de forma uniforme a cada sector en CER, por tanto, son esquemas que no presentan una estrategia de asignación de recursos para los esquemas de femtoceldas densos que cambian de forma dinámica. Así, el aporte de este trabajo consiste en ajustar de forma adaptativa la proporción de CCR y el factor de reutilización de frecuencia en CER, y asignar bloques de recursos para cada sector de forma proporcional. De esta forma se define un modelo de sistema con tres aspectos: la división de regiones, que define los radios de cobertura de las macroceldas y las femtoceldas; la distribución de usuarios, donde se asumen dos conjuntos, Usuarios de Macro Celdas [Macro User Equipment, MUE] y Usuarios de Femto Celdas [Femto User Equipment, FUE]; y el aspecto resource allocation, donde se asume un conjunto total de bloques de recursos [RB]. Además, en este trabajo se define un escenario con una densidad de cien usuarios distribuidos uniformemente sobre la macro-celda y un usuario por femto-celda, con un total de 100 femto-celdas, así pues, se involucra un esquema FFR inteligente.

\section{Conclusiones}

La coordinación de interferencia inter-celda es un problema de mucho interés en LTE y LTE-A, por la complejidad actual de estas redes, debida a la alta densidad de usuarios y a la
Kashaf et al., (2017) propose an approach based on GA to reduce the interference in LTE networks and, at the same time, improve the network performance. Their solution operates in an environment with variable traffic, user positions, and propagation conditions. These variations are modelled with non-linear and probability functions. GA is a machine learning technique that models the biological process of evolution by involving the concept of generations where, in this case, represents the scenario to improve the network KPI. Several generations are simulated to achieve the self-optimization with the most adequate results. The optimized KPI are denoted as acceptance rate and they represent the file transfer time and the average bit speed. For the system modelling, the frequency is divided in three subbands: one in the edge, two in the central region. The users with the worst channel quality are assigned to the protected edge band; although they are mainly in the cell edges, they also can be in the center and experiment fading conditions. If the edge band in a cell is completely busy, the remaining users present an allocation of PRB in the central bands. The simulation results show improvements in the call average successful ratio of calls and in the throughput.

Gao et al., (2014) propose the Intelligent Fractional Frequency Reuse [I-FFR] for an LTE network with femtocells by considering two regions: Cell Center Region [CCR] and Cell Edge Region [CER]. This latter is divided in sectors and a combination of genetic with graph recognition algorithms is applied; this because in the FFR conventional schemes, the CCR relation and the reuse factor in CER are fixed. Furthermore, the RB are distributed in a uniform way to each sector in CER. Consequently, they are schemes that do not present a resource allocation strategy for the schemes with dense femtocells that change dynamically. Hence, the main contribution of this work consists of adjusting the CGR proportion and the reuse factor in GER adaptively, achieving the allocation of resource blocks for each sector in a proportional manner. Consequently, a system model with three aspects is defined: the region division defining the coverage ratios of the macro and femtocells; the users' distribution where two sets are assumed: Macro User Equipment [MUE] and Fem to User Equipment [FUE]; and the resource allocation aspect where a total set of RBs is assumed. Further, this work also defines a scenario with a density of 100 users evenly distributed in the macrocell and a single user per femtocell. This entails a total of 100 femtocells and the involving of a FFR intelligent scheme is involved.

\section{Conclusions}

The intercell interference coordination is a problem with growing interest in LTE/LTE-A networks due to the current complexity of these networks caused by the high users' 
density and the variable load traffic and the deployments of heterogeneous networks. Although there are many techniques to address the ICI issue including the frequency reuse, these are static techniques that do not adapt to the high traffic variations in the current networks.

The machine learning techniques are schemes that allow the ICI to be treated from the point of view of the self-organization, i.e., grant that the cellular networks have the capacity to adjust its network parameters and adapt to the environment variations. In order to achieve efficient algorithms, it is necessary to ensure a careful data processing, parameter that in the mobile network area, is represented by the network parameters (inputs) and the metrics to assess or KPI (outputs).

To tackle the ICI issue through ML, it is recommendable to generate a flow diagram where the input parameters to use are defined - e.g., the amount and distribution of UEs, the power and distribution of macro and micro cells, etc.Secondly, define the expected results through the KPI selection - e.g., throughput and spectrum efficiency —, to finally generate the model in charge of training the algorithm. In this last step, the selection of the ML technique and the definition of the mathematical model should be done. Although it is true that there are many ML techniques, the selection of the most adequate depends of the type of available data, the environment of the problem, and the expected results for each particular case.sT carga variable de tráfico, así como a los despliegues de redes heterogéneas. Aunque existen muchas técnicas para abordar el problema de la ICI, entre ellas el reuso de frecuencia, son técnicas estáticas que no se adaptan a las altas variaciones de tráfico de las redes actuales.

Las técnicas de aprendizaje automático o de ML son esquemas que permiten que la ICI se pueda tratar desde el punto de vista de la auto-organización, es decir, que las redes celulares logren la capacidad de ajustar sus parámetros de red y adaptarse a las variaciones del entorno. Para lograr algoritmos eficientes se necesita un procesamiento de datos cuidadoso, suministro que, en el ámbito de las redes móviles, está representado por los parámetros de la red (entradas) y las métricas a evaluar o KPI (salidas).

Para abordar el problema de la ICI a través de ML es recomendable generar un diagrama de flujo o de bloques donde se defina: en primer lugar, los parámetros de entrada a utilizar - por ejemplo, la cantidad y distribución de UE, la potencia y distribución de celdas macro y micro-; en segundo lugar, los resultados esperados a través de la selección de los KPI - por ejemplo, el throughput y la eficiencia espectral-; y finalmente generar el modelo encargado del proceso para entrenar al algoritmo, paso en el que se haría la selección de la técnica de ML y se definiría el modelo matemático involucrado. Si bien es cierto que existen muchas técnicas ML, la selección de una u otra depende de: el tipo de datos disponibles, el entorno del problema y los resultados que se esperan para cada caso particular. $\mathbf{S C}$ 


\section{References / Referencias}

3GPP. (2014). 3GPP work items on Self-Organizing Networks v0.1.3 (Release 8). 3GPP.

5GAmericas. (2013). Self-optimizing networks: The benefits of SON in LTE. Retrieved from: http://www.5gamericas.org/files/7714/0759/1264/Self-Optimizing_Networks-Benefits_of_SON_in_LTE_10.7.13.pdf

Abusaid, O. \& Salem, F. (2017). Self-organizing techniques to resource block scheduling in LTE-A communication systems. Engineering and Technology (ICET), 2017 International Conference on (pp. 1-6). Antalya: IEEE. doi:10.1109/ICEngTechnol.2017.8308183

Barranco, R. (2012, June 18). IBM. Retrieved from: https://www.ibm.com/developerworks/ssa/local/im/que-es-big-data/quees-big-data-pdf.pdf

Behjati, M. (2014). Self-organizing interference coordination for future LTE-advanced network QoS improvements. In Broadband Multimedia Systems and Broadcasting (BMSB), 2014 IEEE International Symposium on. Dublin. doi:10.1109/ BMSB.2014.6873493

Bojović, B., Meshkova, E., Baldo, N., Riihijärvi, J., \& Petrova, M. (2016). Machine learning-based dynamic frequency and bandwidth allocation in self-organized LTE dense small cell deployments. Eurasip Journal on Wireless Communication Network, 143. doi: 10.1186/s13638-016-0679-0

Borkar, S., \& Pande, H. (2016). Application of 5G next generation network to Internet of Things. Internet of Things and Applications (IOTA), International Conference on. Pune. IEEE. doi:10.1109/IOTA.2016.7562769

Budihal, V., Sandhya, R., Siddamal, S., \& Banakar, R. M. (2016). Framework for intercell interference avoidance in MIMO OFDMA system. Wireless Communications, Signal Processing and Networking (WiSPNET), International Conference on (pp. 1626-1630). Chennai: IEEE.

Cordina, M., \& Debono, C. J. (2017). A support vector machine based sub-band CQI feedback compression scheme for 3GPP LTE systems. In Wireless Communication Systems (ISWCS), 2017 International Symposium on (pp. 325-330). Bologna. IEEE.

Daeinabi, A., \&Sandrasegaran, K. (2014). Networks: A fuzzy Q-learning approach for enhanced intercell interference coordination in LTE-Advanced heterogeneous. In Communications (APCC), 2014 Asia-Pacific Conference on (pp. 139-144). Pattaya. IEEE.

Dai, K., \& Hiroyuky, S. (2012). Intercell interference coordination (ICIC) Technology. Fujitsu Sci. Tech., 48(1), 89-94.

Deb, S. (2014). Algorithms for enhanced inter-cell interference coordination (eICIC) in LTE HetNets. IEEE/ACM Transactions on Networking, 22(1), 137-150.

Eberle, A. (2015, Mach 15). Markov processes. Retrieved from: http://wt.iam.uni-bonn.de/fileadmin/WT/Inhalt/people/Andreas Eberle/MarkovProcesses/MPSkript1415.pdf

ETSI TS 136423 V11.2.0. (2018, April). Retrieved from: http://www.etsi.org/deliver/etsi ts/136400 136499/136423/11. 02.00_60/ts_136423v110200p.pdf

Feng, S. (2008). Self-organizing networks (SON) in 3GPP long term evolution. Munich, Germany: Nomor Research.

Fernández, B., González, L., \& Hernández, C. (2014). Impacto del reuso de frecuencia fraccional en la reducción de interferencia intercelda en LTE. Revista de Investigaciones, 25(1), 28-39.

Gadam, M., Ahmed, M. A., \& Kyun, C. (2016). Wireless personal communications: A review of adaptive cell selection techniques in LTE-advanced HetNets. Journal of Computer Networks and Communications, 2016, Art.3. doi:10.1155/2016/7394136

Galindo-Serrano, A., \& Giupponi, L. (2013). Self-organized femto-to-macro interference coordination with partial information. In Personal, Indoor and Mobile Radio Communications (PIMRC Workshops), 2013 IEEE 24th International Symposium on (pp. 111-116). London. IEEE.

Gao, C., Chen, X., \& Li, L. (2014). An I-FFR algorithm for interference coordination in twin-layer femtocell networks. In Game Theory for Networks (GAMENETS), 2014 5th International Conference on. Beijing: IEEE. doi:10.1109/GAMENETS.2014.7043724

Glenn, O., Imran, A., \& Evans, M. I. (2013). A Survey of Self Organization in Future Cellular Networks. IEEE Communications Surveys \& Tutorials, 15(1), 336-361.

Guio, I. \& Hernández, M. Á. (2013). Gestión de recursos radio en redes móviles celulares basadas en tecnología OFDMA para la provisión de QoS y control de la interferencia [tesis]. Universidad de Zaragoza: España.

Hajjar, M., Aldabbagh, G., \& Dimitriou, N. (2015). Using clustering techniques to improve capacity of LTE networks. In Communications (APCC), 2015 21st Asia-Pacific Conference on (pp. 68-73). Kyoto. IEEE.

Hamza, A., Khalifa, S., \& Hamza, H. (2013). A survey on inter-cell interference coordination techniques in OFDMA-based cellular networks. IEEE Communications Surveys \& Tutorials, 15(4), 1642-1670.

Hinton, G., Srivastava, N., \& Swersky, K. (2014, April). Neural networks for machine learning - Lecture 1A [slides]. Retrieved from: https://www.cs.toronto.edu/ tijmen/csc321/slides/lecture_slides_lec1.pdf

Hu, T., \& Pang, J. (2012). LTE-Advanced heterogeneous networks: Release 10 and beyond. In Communications (ICC), 2012 IEEE International Conference on. Ottawa. IEEE. doi:10.1109/ICC.2012.6364785.

Jain, S. (July 31). Introduction to genetic algorithm \& their application in data science. Retrieved from: https://www.analyticsvidhya.com/blog/2017/07/introduction-to-genetic-algorithm/

Jiang, C., Zhang, H., Ren, Y., Han, Z., Chen, K.-C., \& Hanzo, L. (2017). Machine learning paradigms for next-generation wireless networks. IEEE Wireless Communications, 24(2), 98 - 105. 
Kashaf, A., Tiwana, M. I., \& Usman, I. (2017). Self-organizing inter-cell interference coordination in 4G and beyond networks using genetic algorithms. Automatika, 58(1), 48-54.

Keysight Technologies (2018, April). LTE physical layer overview. Retrieved from: http://rfmw.em.keysight.com/wireless/helpfiles/89600b/webhelp/subsystems/lte/content/lte overview.htm

Kibria, M. G., Villardi, G. P., \& Nguyen, K. (2016). Heterogeneous Networks in Shared Spectrum Access Communications. IEEE Journal on Selected Areas in Communications, 35(1), 45-58.

Klaine, P., Imra, M., Onireti, O., \& Souza, R. (2017). A survey of machine learning techniques applied to self-organizing cellular networks. IEEE Communications Surveys \& Tutorials, 19(4), 2392-2431.

Kumar, D., Kanagaraj, N. N., \& Srilakshmi, R. (2013, April). Harmonized Q-learning for radio resource management in LTE based networks. In ITU Kaleidoscope: Building Sustainable Communities (K-2013), 2013 Proceedings of (pp. 1-8). IEEE.

Li, H., Liang, Z., \& Ascheid, G. (2016). Artificial neural network aided dynamic scheduling for elCIC in LTE HetNets. In Signal Processing Advances in Wireless Communications (SPAWC), 2016 IEEE 17th International Workshop on (pp. 1-5). Edinburgh: IEEE. doi:10.1109/SPAWC.2016.7536877

Li, L., Peng, M., Yan, Z., Zhao, Z., \& Li, Y. (2016). Success coverage probability for dynamic resource allocation in small cell networks. In IEEE Wireless Communications and Networking Conference (WCNC) (pp. 1-5). Doha. IEEE. doi:10.1109/ WCNC.2016.7565150

Madariaga, D. F., Rodríguez, J. L., Lozano, M. R., \& Vallejo, E. C. (2013). Inferencia estadística: módulo de regresión lineal simple. Documentos de Investigación, 147. Retrieved from: http://www.urosario.edu.co/Administracion/documentos/Documentos-de-Investigacion/BI_147-Web.pdf

Ming, C., Ye, H., \& Xinyu, G. (2017). A self-organizing resource allocation strategy based on Q-learning approach in ultra-dense networks. In Network Infrastructure and Digital Content (IC-NIDC), 2016 IEEE International Conference on (pp. 155-160). Beijing. IEEE.

Miramá, V., \& Quintero, V. (2016). Control de potencia basado en teoría de juegos en sistemas de comunicaciones inalámbricas. Gerencia Tecnológica Informática, 15(42), 69-78.

Mohamed, A., \& Abd-Elnaby, M. (2016). Self-organised dynamic resource allocation scheme using enhanced fractional frequency reuse in long term evolution-advanced relay-based networks. IET Communications, 10(10), 1163-1174.

Morel, M.-L. A., \& Randriamasy, S. (2017). Quality of experience-aware enhanced inter-cell interference coordination for self organized HetNet. In Wireless and Mobile Networking Conference (WMNC), 2017 10th IFIP (pp. 1-8). Valencia. IEEE. doi:10.1109/WMNC.2017.8248841

Morozs, N., Clarke, T., \& Grace, D. (2015). Distributed heuristically accelerated q-learning for robust cognitive spectrum management in LTE cellular systems. IEEE Transactions on Mobile Computing, 15(4), 817-825.

Moysen, J., Giupponi, L., Carl, A., \& Gauss, F. (2014). A reinforcement learning based solution for self-healing in LTE networks. In 2014 IEEE Vehicular Technology Conference (VTC Fall). Vancouver. IEEE. doi:10.1109/VTCFall.2014.6965842

ns-3 (2011). ns-3 A discrete-event network simulator. Retrieved from: https://www.nsnam.org/docs/models/html/lte-design. $\mathrm{html}$

Qi, W., Zhang, B., Chen, B., \& Zhang, J. (2018). A user-based K-means clustering offloading algorithm for heterogeneous network. In 2018 IEEE 8th Annual Computing and Communication Workshop and Conference (CCWC), Las Vegas, NV (pp. 307-312). IEEE.

Rayón, A. (2017, April). Guía para comenzar con algoritmos de machine learning. Retrieved from: https://blogs.deusto.es/ bigdata/guia-para-comenzar-con-algoritmos-de-machine-learning/

Razavi, R., Klein, S., \& Claussen, H. (2010). Self-optimization of capacity and coverage in LTE networks using a fuzzy reinforcement learning approach. In Personal Indoor and Mobile Radio Communications (PIMRC), 2010 IEEE 21st International Symposium on. Instanbul. IEEE. doi:10.1109/PIMRC.2010.5671622

Shanthamallu, U., Spanias, A., Tepedelenlioglu, C., \& Stanley, M. (2017). A brief survey of machine learning methods and their sensor and IoT applications. In Information, Intelligence, Systems \& Applications (IISA), 2017 8th International Conference on (pp. 1-8). Larnaca, Cyprus. IEEE. doi:10.1109/IISA.2017.8316459

Sierra, C. A. \& Marca, J. R. (2015). Load balancing in self-organized heterogeneous LTE networks: A statistical learning approach. In 2015 7th IEEE Latin-American Conference on Communications (LATINCOM). Arequipa. IEEE. doi:10.1109/ LATINCOM.2015.7430131

Supratim D. \& Monogioudis, P. (2015). Learning-based uplink interference management in 4G LTE cellular systems. IEEEACM Transactions on Networking, 23(2), 398 - 411

Thilina, K. M., Choi, K. W., Saquib, N., \& Hossain, E. (2013). Machine learning techniques for cooperative spectrum sensing in cognitive radio networks. IEEE Journal on Selected Areas in Communications, 31(11), 2209-2221

Trabelsi, N., Chen, C. S., Azouzi, R. E., Roullet, L., \& Altman, E. (Junio de 2017). User association and resource allocation optimization in LTE cellular networks. IEEE Transactions on Network and Service Management, 14(2), 429-440.

Van den Berg, J. L., Litjens, R., Eisenblätter, A., Amirijoo, M., Linnell, O., Blondia, C., ... \& Schmelz, L. C. (2008). Self-organisation in future mobile communication networks. In Proceedings of ICT-Mobile Summit 2008, Stockholm, Sweden, 2008. Retrieved from: http://citeseerx.ist.psu.edu/viewdoc/download?doi=10.1.1.302.3075\&rep =rep1\&type = pdf

Xie, Z. (2009). Enhanced fractional frequency reuse to increase capacity of OFDMA Systems. In Proceedings of the 3rd International Conference on New Technologies, Mobility and Security, NTMS. Cairo, Egypt: IEEE. doi:10.1109/ NTMS.2009.5384757. 


\section{CURRICULUM VITAE}

Omar Trejo Narváez Engineer in Electronic and Telecommunications (2008) and Specialist in Network and Telematics Services (2011) form the Universidad del Cauca (Popayan, Colombia). He is a Master in Electronic and Telecommunications' student and member of New Technologies in Telecommunications Research Group [GNTT] at the Universidad del Cauca. He is full professor at the Basic Sciences, Technology and Engineering School and member of the Research Group in Technological Development [GIDESTEC] at the Universidad Abierta y a Distancia [UNAD]. His main areas of interest are electronics and telecommunications with emphasis in telematics networks management, next generation networks and electric circuits labs / Ingeniero en Electrónica y Telecomunicaciones (2008), Especialista en Redes y Servicios Telemáticos (2011) y estudiante de la Maestría en Electrónica y Telecomunicaciones de la Universidad del Cauca (Popayán, Colombia). Miembro del Grupo de Investigación Nuevas Tecnologías en Telecomunicaciones [GNTT] de la Universidad del Cauca y del Grupo de Investigación en Desarrollo Tecnológico [GIDESTEC] de la Universidad Nacional Abierta y a Distancia [UNAD]. Docente de tiempo completo en la Escuela de Ciencias Básicas Tecnología e Ingeniería de la UNAD, orienta sus labores en las áreas de electrónica y telecomunicaciones, específicamente en gestión de redes telemáticas, redes de nueva generación y laboratorios del área de circuitos eléctricos.

Víctor Miramá Pérez Engineer in Electronic and Telecommunications (2008) and Master in Electronics and Telecommunications (2013) from the Universidad del Cauca (Popayán, Colombia). Professor at the Telecommunications Department and member of the New Technologies in Telecommunications Research Group [GNTT] and the Radio and Wireless Group [GRIAL] at the Universidad del Cauca. His main areas of interest are mobile and wireless telecommunications / Ingeniero en Electrónica y Telecomunicaciones (2008) y Magister en Electrónica y Telecomunicaciones (2013) de la Universidad del Cauca (Popayán, Colombia). Es docente del Departamento de Telecomunicaciones e investigador en el Grupo de Investigación Nuevas Tecnologías en Telecomunicaciones [GNTT] y del Grupo de Radio e Inalámbricas [Grial] de la Universidad del Cauca. Orienta sus labores de docencia e investigación en las áreas de comunicaciones móviles e inalámbricas. 